\title{
The Myth of Post-Reform Income Stagnation in Brazil
}

\author{
Irineu de Carvalho Filho and \\ Marcos Chamon
}





\title{
IMF Working Paper
}

Western Hemisphere and Research Departments

The Myth of Post-Reform Income Stagnation in Brazil

Prepared by Irineu de Carvalho Filho and Marcos Chamon ${ }^{1}$

Authorized for distribution by Sanjaya Panth and Paolo Mauro

December 2006

\begin{abstract}

\section{This Working Paper should not be reported as representing the views of the IMF.}

The views expressed in this Working Paper are those of the author(s) and do not necessarily represent those of the IMF or IMF policy. Working Papers describe research in progress by the author(s) and are published to elicit comments and to further debate.
\end{abstract}

This paper uses Engel curves to estimate real income growth in Brazil. The estimated per capita household real income growth in metropolitan areas during 1987-2002 is about $4 \frac{1}{2}$ percent per year, well above the "headline" growth of $1 \frac{1}{2}$ percent obtained by deflating nominal incomes by the CPI. This suggests a substantial CPI bias during that period, likely owing to one-off effects of trade liberalization and inflation stabilization. The estimated unmeasured gains are higher for poorer households, implying a marked reduction in "real" inequality. This finding challenges the conventional wisdom that post-reform real income growth in Brazil was low.

JEL Classification Numbers:D12; E01; I32; O10; F15

Keywords: CPI bias, Trade Liberalization, Inflation Stabilization, Economic Reform Authors' E-Mail Addresses: idecarvalhofilho@imf.org; mchamon@imf.org

\footnotetext{
${ }^{1}$ We are grateful to Martin Cerisola, Dora Costa, Angus Deaton, Marcello Estevão, André Faria, Francisco Ferreira, Michael Kremer, Timothy Lane, Paolo Mauro, Jeromin Zettelmeyer and seminar participants at the IMF, the World Bank Microeconomics of Growth Conference, EEA 2006, LACEA 2006, and IMF/WHD Department Workshop 2006 for helpful comments. Any errors are our own.
} 


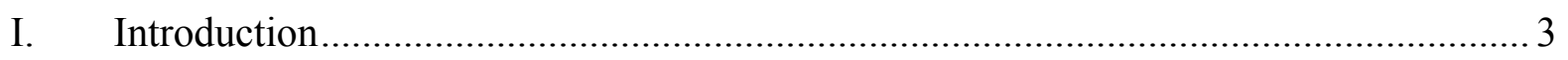

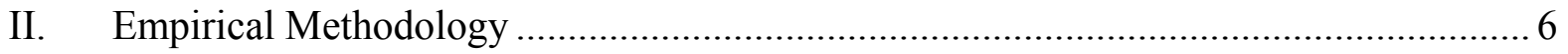

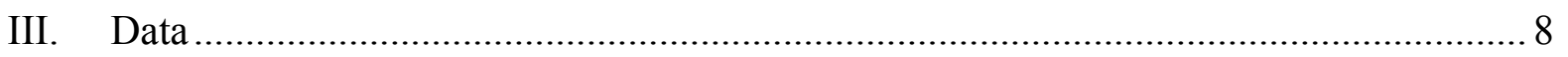

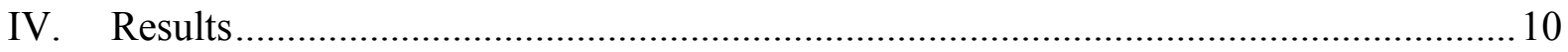

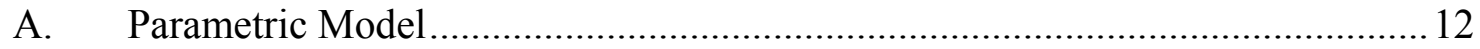

B. Semi-Parametric Model ............................................................................... 12

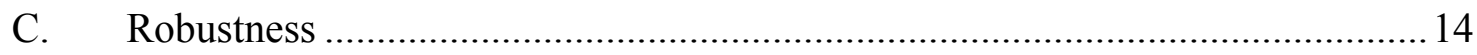

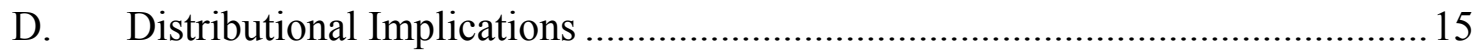

V. Evidence From Durable Goods Ownership and Anthropometrics ............................ 15

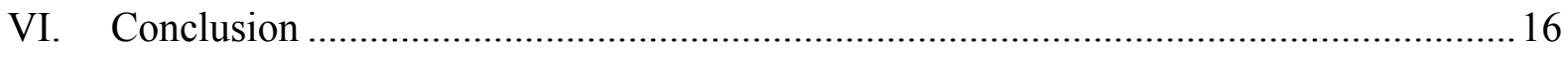

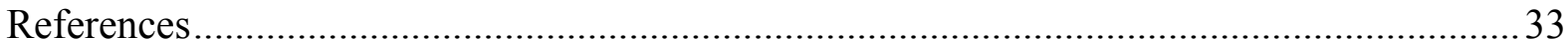

Tables

1. Mean Expenditure Shares, Median Total Expenditure, by Expenditure Quintile in

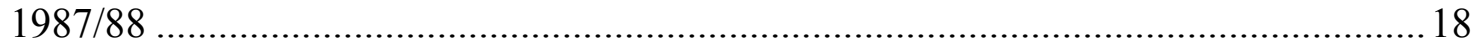

2. Descriptive Statistics for Regression .............................................................. 19

3. Regression Results for Pooled Sample............................................................... 20

4. Bias Estimates Across Different Methods and Samples .......................................... 21

5. Household Per Capita Expenditure and Net Income: Headline and Corrected .............22

6. Expenditure Inequality Corrected for CPI Bias: Expenditure Gini Coefficients...........23

7. Ownership of Durable Goods, and Sensitivity to Income .....................................24

8. Anthropometric Measures for Children 0-60 Months Old .......................................25

Figures

1. GDP Per Capita and Average Growth In Decade for Brazil ....................................26

2. Food Budget Share by Expenditure Deciles ........................................................26

3A. Food Budget Share by Metropolitan Area ........................................................... 27

3B. Food Expenditure Per Capita, by Metropolitan Area ............................................ 27

4. Changes in Relative Prices................................................................................ 28

5. Non-Parametric Estimates of Relationship between Food Shares and Household

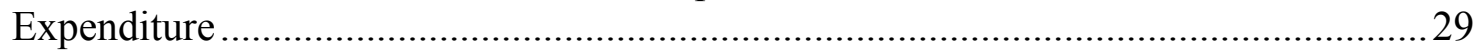

6. Estimated Bias in 1987/88-1995/96 as a Function of CPI-Measured Real Expenditure

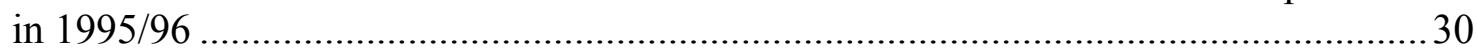

7. Estimated Bias in 1995/96-2002/03 as a Function of CPI-Measured Real Expenditure

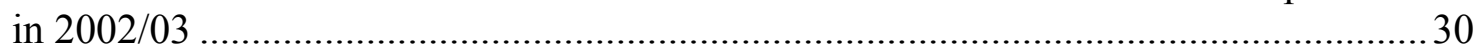

8A. Distribution of Expenditure Deflated by the CPI: 87/88, 95/96 and 02/03 _............... 31

8B. Distribution of Expenditure Deflated by the Estimated True Cost of Living Index:

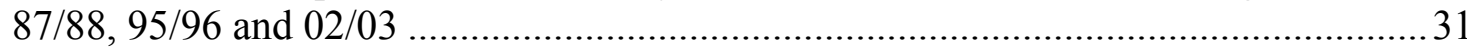

9. Changes in Durable Goods Holdings and Sensitivity to Income .............................. 32 


\section{INTRODUCTION}

The post-reform economic growth experience in Latin America has failed to fulfill the high expectations held at the time those countries embarked on their trade liberalization and privatization efforts. As early as 1995, a number of observers, such as Krugman (1995) and Easterly, Loayza, and Montiel (1997) started to wonder whether Latin America's post-reform growth had been disappointing. A decade later, economists remain disappointed and somewhat puzzled at how economic growth failed to pick up despite the removal of so many distortions from those economies. In this paper we present household-level evidence that conventional measures of real income growth grossly underestimate the true post-reform income growth for Brazil. It is possible that the same applies to a number of other Latin American countries.

After several decades of very high growth in per capita GDP, the Brazilian economy came to a halt in the 1980s, with growth during that decade essentially zero (Figure 1). The conventional wisdom at that time was that such economic stagnation was the consequence of the failure of the import-substitution development strategy at coping with adverse external shocks. Hence, expectations were high when Brazil began to open up and liberalize its economy. For decades, Brazil had been one of the world's most closed economies, with very high tariff and non-tariff barriers, including outright bans on the importation of several goods. In the late 1980s/early 1990s, Brazil began to cut tariffs substantially and to dismantle most non-tariff barriers; and by the mid-1990s it was already a relatively open economy (particularly in comparison with its former self). ${ }^{2}$ Although import penetration remained relatively small as a percentage of GDP, competitive pressures following trade liberalization led to dramatic improvements in the productivity of Brazilian manufacturing firms. ${ }^{3}$ Inflation was finally brought under control in 1994, with the Plano Real, after decades of chronic high inflation. But, as Figure 1 indicates, Brazil's post-reform growth apparently never lived up to reformers' optimistic expectations. ${ }^{4}$

There is an extensive literature arguing that changes in the Consumer Price Index (CPI) overestimate the increase in cost of living in the United States. ${ }^{5}$ One of the main sources of CPI overestimation is the late introduction of new goods into the CPI basket. It is often the case that new goods are initially very expensive and only consumed by a few households. But over time, new goods tend to become cheaper and more widely consumed. The longer it takes

\footnotetext{
${ }^{2}$ The (unweighted) average tariff for 53 final goods collected by Kume, Piani, and de Souza (2000) declines from 55 percent in 1987 to 31 percent in 1990, and to only 11 percent in 1995.

${ }^{3}$ Ferreira and Rossi (2003) attribute an increase in annual Total Factor Productivity (TFP) growth in Brazilian industry of more than 5 percent during 1991-97 to the effects of trade liberalization. Muendler (2001) finds that increased foreign competition pressured Brazilian manufacturers to raise productivity markedly during the same period.

${ }^{4}$ Although the focus of this paper is on household income growth, GDP growth was used in Figure 1 and in the motivation owing to its broader historical coverage.

${ }^{5}$ For an overview of this literature, see National Research Council (2002) and Hausman (2003).
} 
for a new good to be introduced into the CPI basket, the less of its price decline that is captured by the CPI index. Another source of CPI overestimation is substitution bias. Consumers tend to economize on goods whose relative prices have increased, while buying greater quantities of goods whose relative prices have declined. The failure to account for this behavior has long been known as a cause of overestimation of the increase in the cost of living, the more so when there are long lags between adjustments of the CPI basket and large changes in relative prices.

As Brazil gradually opened its economy to international trade in the late 1980s/early 1990s, many innovations that were gradually introduced in the United States suddenly became available and more affordable to Brazilian households. However, the first post-liberalization revision of the Brazilian CPI took place only in 1999, based on the 1995/96 expenditure survey (e.g. it was only then that computers and cell phones were introduced into the CPI basket and large revisions took place on the weights of some goods). ${ }^{6}$ This "catching-up" effect combined with a relatively late adjustment in the CPI basket suggests that, during the sample period, the CPI bias in Brazil may have been much larger than that in the United States. $^{7}$ Another potentially important source of bias is the CPI's failure to account for quality improvements in existing goods, which were also considerable in the post-reform Brazil of the 1990s.

The stabilization of inflation achieved by the Plano Real in 1994 may also have translated into improvements in living standards not fully captured by standard measures of real income. Neri (1995) calculates that bringing down inflation from 40 percent to 1 percent per month increases the purchasing power of those without access to short-term financial investments by 9 percentage points. Since the poor are less likely to have interest-earning bank accounts, they are worse-off under hyperinflation relative to a low-inflation environment even after adjusting their income by CPI inflation.

We calculate the real income growth in Brazil implied by Engel curves, following the method used by Nakamura (1997), Costa (2001) and Hamilton (2001) for the United States. Engel's law states that the share of food in total household expenditures declines as (real) income grows, and it is among the strongest empirical regularities in economics. ${ }^{8}$ We estimate a model for household-level budget share of food as a function of real income, relative prices, and household characteristics, using data from three different household surveys. By comparing the real income growth implied by the observed changes in the budget share of

\footnotetext{
${ }^{6}$ For example, the weight of automobile purchases in the CPI basket doubled following this revision, going from 1.01 percent to 3.38 percent for new automobiles and from 1.42 percent to 2.29 percent for used ones.

${ }^{7}$ Although the time intervals between updates in Brazil's CPI basket are not unusually long, their timing was such that the first update reflecting post-liberalization consumption patterns only took place in 1999, a decade after the liberalizing reforms began.

8 "Of all empirical regularities observed in economic data, Engel's Law is probably the best established; indeed it holds not only in the cross-section data where it was first observed, but has often been confirmed in time-series analysis as well" (Houthakker, 1987).
} 
food with the "headline" real income growth obtained by deflating nominal income by the CPI, we can estimate the mismeasurement of the latter. Assuming nominal income is measured accurately, we attribute the difference between the real income growth based on our estimate of the true cost of living and the "headline" real income growth to measurement error in the CPI. This approach can capture the overall mismeasurement of real income that may result from factors such as the late introduction of new goods into the CPI bundle, consumer substitution, increases in the durability of goods, improvements in distribution networks, and mismeasurement of prices. It can also capture bias owing to improvements in the quality of goods to the extent there is substitution away from luxury foods toward the goods whose quality has improved. This paper also focuses on distributional issues as it uses a semiparametric methodology that allows for variation in the estimated bias at different points in the income distribution.

Household income and expenditure surveys were conducted in Brazil in 1987/88, 1995/96, and 2002/03. During the time span of those surveys, the budget share of food declines from poorer to richer expenditure quantiles, and has also declined over time within each quantile and across the income distribution.

Costa (2001) and Hamilton (2001) estimate the CPI bias in the United States at roughly 1 percentage point per year since the 1980s. Their estimates are similar to those of the Boskin Commission, which estimated the bias at 1.1 percentage points per year in 1995-96 (Boskin and others, 1996). Comparison with those estimates suggests a much more sizable understatement of real income growth in Brazil. Our preferred bias estimates imply that for households in the metropolitan areas covered by the CPI, there was a discrepancy between the gross change in the true cost of living and the gross change in the "headline" CPI of about 3 percent per year during 1987/88-2002/03. ${ }^{9}$ This implies that real income growth was substantially higher than the headline growth obtained by deflating nominal incomes by the CPI.

When our estimates allow the bias to vary with household expenditure levels, we find larger unmeasured improvements in real income for poorer households, implying a substantial reduction in income inequality when measured in real terms. This pattern is at least partly driven by high inflation disproportionately hurting the poor, as suggested by Neri (1995). The aggregate bias estimates of 3 percent per year are obtained by averaging the bias estimates at different levels of expenditure, weighting by household expenditure (since the CPI itself is based on an aggregate consumption bundle where individual household bundles are weighted by their expenditure). The bias facing the typical household in the sample (corresponding to the average bias estimated weighted by population and sampling weights), is about 5 percent per year.

The remainder of this paper is organized as follows. Section II describes the methodology. Section III describes the data. Section IV presents the main results, based on Engel curves for

\footnotetext{
${ }^{9}$ That is, if the change in the CPI in a given period were 10 percent and the estimated bias 3 percent, the estimated change in the true cost of living would be 6.7 percent, since $(1-0.03) \cdot 1.1=1.067$.
} 
food consumption. Section V presents alternative corroborating evidence based on ownership of durable goods and anthropometrics. Section VI concludes.

\section{EMPIRICAL METHODOLOGY}

Our parametric estimates of real income growth follow the method developed in Costa (2001) and Hamilton (2001), building on an insight by Nakamura (1997). We start with the demand function for food that emerges from Deaton and Muellbauer's (1980) Almost Ideal Demand System:

$$
\begin{aligned}
w_{i, j, t}= & \phi+\gamma\left(\ln P_{F, j, t}-\ln P_{N, j, t}\right) \\
& +\beta\left(\ln Y_{i, j, t}-\ln P_{G, j, t}\right) \\
& +\sum_{x} \theta_{x} \mathbf{X}_{i, j, t}+\mu_{i, j, t}
\end{aligned}
$$

where the subscripts refer to household $i$, region $j$, and period $t ; w$ is the share of food in total household expenditures; $P_{F}, P_{N}$ and $P_{G}$ are the true but unobservable price indices of food, nonfood and the general index for all goods; $Y$ is the household's nominal expenditure; $\mathbf{X}$ is a vector of household characteristics; and $\mu$ is the residual. A negative $\beta$ characterizes a necessity good while a positive $\beta$ characterizes a luxury or superior good. The true price index $P_{G}$ is measured with CPI error. Let $\Pi_{G, j, t}$ denote the percent cumulative increase in the CPI measured price and $E_{G, j, t}$ denote the percent cumulative measurement error from period 0 to period $t$, for food, nonfood or all goods, as indicated by the subscript. Equation (1) can be rewritten as:

$$
\begin{aligned}
w_{i, j, t}= & \phi+\gamma\left(\ln \left(1+\Pi_{F, j, t}\right)-\ln \left(1+\Pi_{N, j, t}\right)\right) \\
& +\beta\left(\ln Y_{i, j, t}-\ln \left(1+\Pi_{G, j, t}\right)\right) \\
& +\gamma\left(\ln P_{F, j, 0}-\ln P_{N, j, 0}\right)-\beta \ln P_{G, j, 0} \\
& +\gamma\left(\ln \left(1+E_{F, j, t}\right)-\ln \left(1+E_{N, j, t}\right)\right)-\beta \ln \left(1+E_{G, j, t}\right) \\
& +\sum_{x} \theta_{x} \mathbf{X}_{i, j, t}+\mu_{i, j, t}
\end{aligned}
$$

We assume that the CPI measurement error does not vary geographically, and rewrite (2) as:

$$
\begin{aligned}
w_{i, j, t}= & \phi+\gamma\left(\ln \left(1+\Pi_{F, j, t}\right)-\ln \left(1+\Pi_{N, j, t}\right)\right) \\
& +\beta\left(\ln Y_{i, j, t}-\ln \left(1+\Pi_{G, j, t}\right)\right) \\
& +\sum_{j} \delta_{j} D_{j}+\sum_{t} \delta_{t} D_{t} \\
& +\sum_{x} \theta_{x} \mathbf{X}_{i, j, t}+\mu_{i, j, t}
\end{aligned}
$$

where $D_{j}$ and $D_{t}$ are regional and time dummies and: 


$$
\begin{gathered}
\delta_{j}=\gamma\left(\ln P_{F, j, 0}-\ln P_{N, j, 0}\right)-\beta \ln P_{G, j, 0} \\
\delta_{t}=\gamma\left(\ln \left(1+E_{F, t}\right)-\ln \left(1+E_{N, t}\right)\right)-\beta \ln \left(1+E_{G, t}\right)
\end{gathered}
$$

All the terms in Equation (3) are observable and once the equation above has been estimated, we are ready to compute the cumulative CPI bias. If food and nonfood are equally biased, then:

$$
\ln \left(1+E_{G, t}\right)=-\delta_{t} / \beta
$$

It seems very likely that mismeasurement is less of a problem for food than for nonfood goods. As a result, to the extent that food is a necessity $(\beta<0)$ and food shares increase with the relative price of food $(\gamma>0)$, one can show that equation (4) in general understates the bias for small positive values of $\gamma$ as in our estimates.

The parametric specification discussed above assumes that all households at a given date face the same bias. In the context of a high inequality country, it is particularly relevant to inquire about differential effects across the income distribution. The estimation of (3) through minimization of squared errors yields an estimate of the bias for the average household. However, the actual CPI index is based on an aggregate consumption bundle that by design disproportionately represents richer households as they account for a disproportionate share of aggregate consumption. Thus, to the extent that the discrepancy between the true cost of living index and the headline CPI varies across the income distribution, there might be substantial differences between the bias facing the average household and the bias for the aggregate consumption bundle, which is the one that maps to the CPI.

The model in equation (3) can be extended to address this concern, by assuming the bias is a linear function of the log of real expenditure:

$$
\ln \left(1+E_{G, i, t}\right)=a_{t}+b_{t}\left(\ln Y_{i, j, t}-\ln \left(1+\Pi_{G, j, t}\right)\right)
$$

Maintaining the same assumption that food and non-food are equally biased and that the bias does not vary by region, one can estimate:

$$
\begin{aligned}
w_{i, j, t}= & \phi+\gamma\left(\ln \left(1+\Pi_{F, j, t}\right)-\ln \left(1+\Pi_{N, j, t}\right)\right) \\
& +\left(\beta+\sum_{t} \lambda_{t} D_{t}\right)\left(\ln Y_{i, j, t}-\ln \left(1+\Pi_{G, j, t}\right)\right) \\
& +\sum_{j} \delta_{j} D_{j}+\sum_{t} \delta_{t} D_{t} \\
& +\sum_{x} \theta_{x} \mathbf{X}_{i, j, t}+\mu_{i, j, t}
\end{aligned}
$$

and obtain the following expression for CPI bias at different points in the expenditure distribution. 


$$
\ln \left(1+E_{G, i, t}\right)=\frac{-\delta_{t}}{\beta}+\frac{\lambda_{t}}{\beta}\left(\ln Y_{i, j, t}-\ln \left(1+\Pi_{G, j, t}\right)\right)
$$

Finally, we can use a flexible non-parametric approach for the bias by estimating a semiparametric version of the demand function (1), allowing for estimation of the bias at different levels of expenditure. This semi-parametric approach facilitates the expenditure-weighting of estimates so as to map into the actual CPI and also enables us to identify the implications of CPI bias for the evolution of the (real) income distribution. Still under the assumption that food and non-food are equally biased and that the bias does not vary by region, we can rewrite (3) as:

$$
\begin{aligned}
w_{i, j, t}= & \phi+\gamma\left(\ln \left(1+\Pi_{F, j, t}\right)-\ln \left(1+\Pi_{N, j, t}\right)\right) \\
& +\sum_{t} f_{t}\left(\ln Y_{i, j, t}-\ln \left(1+\Pi_{G, j, t}\right)-\ln \left(1+E_{G, i, t}\right)\right) \\
& +\sum_{x} \theta_{x} \mathbf{X}_{i, j, t}+\mu_{i, j, t}
\end{aligned}
$$

We estimate $f_{t}\left(\ln Y_{i, j, t}-\ln \left(1+\Pi_{G, j, t}\right)-\ln \left(1+E_{G, i, t}\right)\right)$ non-parametrically using the differencing method described in Yatchew (1997). ${ }^{10}$

The bias at a given CPI-measured real income level at time $t$ is then estimated as the increase in CPI-measured real income that would have prevented the Engel curves from shifting. That is, we solve at each expenditure level for the value of $E_{G, i, t}$ that satisfies:

$$
\widehat{f}_{t}\left(\ln Y_{i, j, t}-\ln \left(1+\Pi_{G, j, t}\right)-\ln \left(1+E_{G, i, t}\right)\right)=\widehat{f}_{0}\left(\ln Y_{i, j, t}-\ln \left(1+\Pi_{G, j, t}\right)\right)
$$

\section{DATA}

The Pesquisa de Orçamentos Familiares (henceforth, POF) is the household income and expenditure survey carried out by the Instituto Brasileiro de Geografia e Estatística (IBGE) and based on probabilistic sample and stratified design. The POF surveys were conducted in 1987/88, 1995/96, and 2002/03. The first survey covers a time when Brazil was still a very closed economy and tariffs choked off most trade in manufactured goods. By the time the second survey was conducted, Brazil was already a relatively open economy (particularly in comparison with its former self) and inflation had already been brought down to single digit levels. Hence, whereas the 1987/88 and 1995/96 surveys were fielded in substantially different economic environments, the changes between 1995/96 and 2002/03 were smaller. The 1987/88 and 1995/96 POF surveys are representative of the household population in 9

\footnotetext{
${ }^{10}$ In a nutshell, the method consists of estimating the parametric terms after differencing the data (under the assumption that $f()$ is a smooth function), and estimating $f($ ), the non-parametric term, on the difference between the dependent variable and the estimated parametric terms in the equation, using locally-weighted linear regressions using quartic kernel weights.
} 
metropolitan regions (Belém in the Northern region; Fortaleza, Recife and Salvador in the Northeast; Rio de Janeiro, Belo Horizonte and São Paulo in the Southeast; Curitiba and Porto Alegre in the South), plus the Distrito Federal and the municipality of Goiânia, in the CenterWest region. The 2002/03 POF was the first to cover a nationally representative sample. In order to make the samples comparable over time, we limit the 2002/03 sample to the geographical sub-sample also covered by the previous surveys. Goiânia is excluded from our sample because it did not have its own region-specific price index prior to 1991. The POF contains household expenditure information on individual goods at a disaggregated level, households' inventory of durable goods, and also demographic, schooling and income characteristics of each household member.

IBGE produces and disseminates the Índice de Preços ao Consumidor Ampliado (IPCA), which is considered Brazil's official consumer price index, and is based on the basket consumed by the POF families. The IPCA is also the broadest measure of consumer prices available, covering all families earning up to 40 times the minimum wage in the geographical areas covered by the POF. A few years after each POF is collected, the IPCA index is reweighed, hence catching-up with changing consumption patterns of Brazilian households. Throughout the paper, we will be referring to the IPCA whenever the CPI in Brazil is mentioned.

The POFs are conducted over a 12-month period. The field work took place in: March 1987-February 1988, October 1995-September 1996, and July 2002-June 2003. Households are asked to provide information on their expenditures, which are collected based on different reference periods depending on the type of expenditure and its frequency. Four reference periods are used: 7 days, 30 days, 90 days, and a longer recall period of either 12 months (2002/03 POF) or 6 months (1987/88 and 1995/96 POFs). ${ }^{11}$

The POF uses six collection instruments for its data: Housing conditions questionnaire, collective expenditures questionnaire, collective expenditures notebook, individual expenditures questionnaire, individual income questionnaire and living conditions questionnaire. Expenditures on items of frequent use by the household were recorded on the collective expenditures notebook. Those items include mainly food, beverages, cleaning and personal hygiene products. That notebook was kept during a 7-day period by the person who manages those expenditures in the household budget. During that period, the expenditures on those frequent use products were recorded, as well as the amount and location of purchase. This notebook is the source of information for expenditures on food and beverages to be consumed at home. Expenditures on food and beverage consumption outside the home were recorded on the individual expenditures questionnaire, which was based on recall over a seven-day reference period.

Given the length of the collection, reference and recall periods, each POF contains expenditure data spanning a 24-month period. In order to make the data comparable across households surveyed over different periods, IBGE deflates or inflates all results to a same

\footnotetext{
${ }^{11}$ Because there are differences in the recall window across POF surveys, inference on expenditure distribution and inequality across surveys could be biased (Deaton and Kozel 2005).
} 
reference date. The reference dates for the POFs used are: October 15, 1987; September 15, 1996; and January 15, 2003. The deflation of expenditure data to the reference date uses itemspecific deflators. ${ }^{12}$ For example, if a household bought rice and beans on March $4^{\text {th }} 2003$, those two expenditures are deflated to January 15, 2003 values using two different deflators. The deflated expenditures are also "annualized" in the POF database, by multiplying the expenditure by a factor equal to 12 months divided by the reference period for the expenditure (for example, a factor of 52 for the seven-days reference period).

In the three surveys, there are respectively 1.0, 3.9 and 4.8 percent of the households in our full sample that failed to report any expenditures in the collective expenditures notebook (which covers mainly food for home consumption and cleaning and hygiene products). It is possible that some of these households did not have any expenditures to report. But it is also likely that some of them may not have complied with filling the collective expenditures notebook, turning it blank regardless of their expenditure behavior. Our preferred estimates will be based on the subset of households with at least one expense record in the collective expenditures notebook, henceforth referred as the "compliant" sample, but we will also present results for the full sample.

\section{Results}

Since our empirical strategy relies on Engel's law, it is useful to document that food is indeed a necessity good. Table 1 shows the budget share of different consumption groups in 1987/88 for each quintile of the total expenditure distribution. The budget share of food indeed strongly declines with total expenditure. While households in the bottom quintile of total expenditure spent on average over 40 percent of their budget on food, the ones in the top quintile spent only 16 percent. In Table 1 , budget shares tend not to vary much with total expenditure for most other groups of goods, with the exception of education and transportation, both superior goods, i.e., goods whose budget share increases with total expenditure. ${ }^{13}$ Households in the bottom half of the distribution spend less than 10 percent of their budget on transportation, whereas households in the top quintile spend over 20 percent, mainly because they usually own a private vehicle.

Figure 2 shows the budget share for food by decile of household expenditure for the three surveys. The budget share of food declines from poorer to richer deciles, as well as over time within each decile. Figure 3A shows the evolution of the average food budget share by metropolitan area. For each area, and for each subsequent pair of years, the budget share of food declines over time. Figure 3B shows per capita food expenditure by metropolitan area for the three survey years. On average, there was an increase in per capita real food expenditure (in 1996 reais) for each subsequent survey. Four metropolitan areas showed improvements between each survey (Recife, Salvador, Curitiba, and Porto Alegre), while for the other areas

\footnotetext{
${ }^{12}$ If prices are not collected for a given item, the price for its sub-group is used.

${ }^{13}$ Goñi, López, and Servén 2006 find that transportation and communication are superior goods for households in Brazil, Colombia, Peru, and Mexico, and education is a superior good for Brazil and Peru, but not for Colombia and Mexico.
} 
there was at least one episode of decline. However, real per capital food expenditure was higher in 2002/03 than in 1987/88 for all metropolitan areas.

Figure 4 shows the relative prices for different groups of goods (vis-à-vis the aggregate price index). Note the persistent increase in the relative price of most "nontradable" goods (e.g., housing and health care), and the large decline in the relative price of most "tradable" goods (e.g., clothing and household supplies) over time. Similar trends are experienced in other countries, and fit the prior of greater technological progress in the tradable sectors. This trend seems to sharpen around the early 1990s, suggesting that trade barriers were previously dampening these secular changes in the relative price of tradable and nontradable goods. The divergence in relative prices shown in Figure 4 highlights the potential for CPI mismeasurement from outdated weights in the consumption basket and substitution bias.

We first estimate "true real income growth" (i.e., growth in income deflated by the true cost of living index) based on equation (3). Following Costa (2001), we use total expenditure instead of income because expenditures better reflect permanent income. Our specification allows for regional variation in relative prices. The controls for household characteristics include dummies for home ownership and rental; gender of the head of the household; presence of a spouse; whether the head of the household, the spouse, or both have labor income; and the number of household members in age groups: 0 to $4 ; 5$ to $9 ; 10$ to $14 ; 15$ to 19 ; and $20+$ years old.

Table 2 provides summary statistics for our "compliant" sample. The average budget share of food was $301 / 2$ percent, $26 \frac{1}{2}$ percent, and $231 / 4$ percent in the $1987 / 88,1995 / 96$, and 2002/03 surveys, respectively. The relative price of food declined between the first two surveys but remained stable afterwards. Average household size declined considerably, as indicated by the stagnant average total household expenditures despite a sizable increase in per capita expenditure. Note that the per capita expenditure on food deflated by the food CPI has increased (even though the food share in the budget has declined). This rules out possible concerns that the declining budget shares may be due to households being forced to cut back on food in order to meet other expenditures. Family composition changed over time, with a reduction in the households where a spouse was present and an increase in the households not headed by a male. The surveys also indicate an increase in the likelihood of the head of the household not having labor income, perhaps due to a combination of tighter labor market conditions, shifting demographics, and expansion of entitlement programs. ${ }^{14}$ Spousal labor remained more stable.

The expenditure data do not include the rental equivalent value of owner-occupied housing. If that value changed over time at a different rate than the general price index, failure to take it into account could bias our estimates for the mismeasurement of the true cost of living. In order to address this problem, we present results for two samples: one including only renters and the other including all households. Note that not all non-renters are owners (some households live in a housing unit provided by others, for example employers or relatives,

\footnotetext{
${ }^{14}$ For evidence on a sizeable effect of cash benefits on labor participation in Brazil, see de Carvalho Filho (2005).
} 
without rent being charged). Since expenditures are potentially measured with error, we also present estimates where income is used as an instrument. This is particularly important because attenuation bias would tend to drive down the absolute value of the coefficient on the $\log$ of expenditure, hence increasing the estimate of the CPI bias in equation (4).

\section{A. Parametric Model}

Table 3 reports the linear regression results for a sample pooling the three surveys. The coefficients on the time dummies are negative and statistically significant, as expected given the average decline in the budget share of food reported in Figure 2. The estimated coefficients on $\log$ expenditure range from -0.07 to -0.09 for the full sample, which implies income elasticities in line with previous estimates for Brazil (e.g., Asano and Fiuza, 2001). The coefficients on the log of the relative price of food are not statistically significantly different from zero (which may reflect competing income and substitution effects, or limited regional variation in relative prices of food). ${ }^{15}$ Table 3 also reports the resulting estimate for the cumulative CPI bias, $E_{G, t}$, which is negative as expected (the values reported correspond to its absolute value). Given that negative bias, the implied gross change in the true cost of living is $\left(1-\left|E_{G, t}\right|\right)$ times the gross change in the CPI, and the resulting gross true real income growth is $1 /\left(1-\left|E_{G, t}\right|\right)$ times the gross real income growth obtained by deflating nominal income by the CPI. For $1987 / 88$ and $1995 / 96$ the implied cumulative bias for our preferred specification, which uses instrumental variables to reduce attenuation bias, was 45.8 percent for the tenant sub-sample and 34.0 percent for the full sample. The corresponding annualized rates are: 6.9 percent and 4.7 percent, respectively. The annualized rates were computed based on the midpoints of the surveys. For 1995/96 and 2002/03 the cumulative bias in the IV specification was 0.3 percent for tenants and 18.1 percent for the full sample. The corresponding annualized rates are 0.0 percent and 2.9 percent, respectively. These estimates indicate a sizable bias, but declining over time. The pattern of initially large and declining estimated bias might be due to the late post-liberalization revision in the CPI basket in 1999 and one-off gains from disinflation between 1987/88 and 1995/96. The cumulative bias between 1987/88 and 2002/03 is very similar to the one in Table 3 if estimated based on two separate regressions using consecutive pairs of surveys.

Table 4 summarizes the estimates above, presents estimates based on different samples, and estimates when the bias is as a linear function of the log of real expenditure, as in equation (5) of the previous section and the semi-parametric specification discussed below.

\section{B. Semi-Parametric Model}

We now turn to the semi-parametric estimation of the model. Figure 5 shows the nonparametric estimates of the relationship between the food budget share and the log of real expenditure. ${ }^{16}$ As expected, the food budget share declines with real expenditure and the

\footnotetext{
${ }^{15}$ This is not likely to affect the thrust of our results since the relative price of food remained roughly constant between the second and third surveys, yet we find substantial CPI bias during that period.

${ }^{16}$ The estimates are based on locally-weighted linear regressions with quartic kernel weights.
} 
curves have shifted downward with each survey. For low levels of expenditure, this relationship is non-monotonic, but the proportion of households in that expenditure range is relatively small. It is anticipated that their contribution to estimated expenditure-weighted aggregate CPI bias. The overwhelming majority of the households are in the expenditure range where the food budget share declines as real expenditure increases.

As discussed in Section 2, the food share-real expenditure profiles in Figure 5 map into a CPI bias-real expenditure profile by computing the necessary change in real expenditure, at each real expenditure level that would maintain the Engel curves in the same position. For example, for each level of expenditure in the 1995/96 survey, CPI bias is determined by its difference to the real expenditure level in 1987/88 that was associated to the same food budget share. For CPI measured real expenditure $R$ we can solve for the corresponding bias in $E_{1995 / 1996}(R)$ as the solution to:

$$
\widehat{f}_{1995 / 96}\left(\ln R-\ln \left(1+E_{1995 / 96}(R)\right)=\widehat{f}_{1987 / 88}(\ln R)\right.
$$

where $\widehat{f}_{1995 / 96}$ and $\widehat{f}_{1987 / 88}$ are the estimated Engel curves for 1995/96 and 1987/88. ${ }^{17}$

Since we rely on Engel's Law, such mapping is only meaningful in the range where the food share is declining on income. The data, however, sometimes shows non-monotonicity of the Engel curve for low levels of expenditure. To address this issue, at the left tail of the expenditure distribution, we set the bias to equal that of the first expenditure level $R^{L}$ in the declining range of the curve for which the food share is below the one for the lowest level of expenditure $R_{\min }$. In more precise terms, we impose the constraint:

$$
\begin{aligned}
& E_{1995 / 96}(R)=E_{1995 / 96}\left(R^{L}\right) \text { if } R<R^{L}, \\
& \text { where } R^{L}=\widehat{f}_{1995 / 96}^{-1}\left(\widehat{f}_{1995 / 96}\left(R_{\min }\right)\right), \hat{f}_{1995 / 96}^{\prime}\left(R^{L}\right)<0
\end{aligned}
$$

At the right-tail of the expenditure distribution, there are levels of the food share in 1995/96 for which there are no counterparts in the 1987/88 Engel curve. In those cases we set the bias to equal that of the highest expenditure level $R^{U}$ in the 1995/96 curve for which the mapping into the $1987 / 88$ curve is still possible (to the highest value of expenditure $R_{\max }$ ). That is:

$$
\begin{aligned}
& E_{1995 / 96}(R)=E_{1995 / 96}\left(R^{U}\right) \text { if } R>R^{U}, \\
& \text { where } R^{U}=R_{\max }\left(1+E_{1995 / 96}\left(R^{U}\right)\right)
\end{aligned}
$$

\footnotetext{
${ }^{17}$ The Engel curves $\widehat{f}$ are obtained after controlling for all the right-hand side variables used in the linear regressions reported in Table 3.
} 
Similarly, the bias from 1995/96 to 2002/03 is estimated by computing the real expenditure growth that would make the 2002/03 Engel curve match the one for 1995/1996, subject to the same adjustments at the tails of the expenditure distribution.

Figure 6 shows the estimated annual bias from 1987/88 to 1995/96 as a function of headline real expenditure, as well as the estimated density function of the log of CPI-deflated real expenditure in 1995/96. The bias is higher for the poorest households, and gradually declines as real expenditure increases. The annualized bias for the average household is $5 \frac{1}{2}$ percent per year, whereas the expenditure weighted aggregate bias is only 2 percent per year. Figure 7 shows the estimated annual bias from 1995/96 to 2002/03. The profile is flatter than the one in Figure 6, suggesting that the differences in CPI bias across the income distribution have narrowed. The bias for the average household is about $4 \frac{1}{2}$ percent while the expenditure weighted aggregate bias is $4 \frac{1}{4}$ percent.

\section{Robustness}

Table 4 reports the estimated biases under different methods and samples. The first set of estimates are based on the linear regression model as in Table 3 . The second set of estimates is based on a parametric specification for the bias as a linear function of the log of real expenditure. Finally, the third set of estimates is based on the semi-parametric approach discussed above. It presents results for four different samples: the preferred "compliant" sample, the full sample, the tenants sample, and a winsorized sample, where the value of food and total expenditures for observations below the $5^{\text {th }}$ and above the $95^{\text {th }}$ percentile are set to the value at that percentile.

For the first period, from $1987 / 88$ to $1995 / 96$, the population sample weighted bias estimates are always above $3 \frac{3 / 4}{4}$ percent per year, and as high as $9 \frac{1}{2}$ percent per year for the full sample and OLS estimates. Since the full sample is likely contaminated by observations that did not report actual expenditure in the survey, these estimates should be read with caution. For the "compliant" sample, IV bias estimates are smaller than OLS ones, which is suggestive of attenuation bias due to mismeasurement of the real expenditure variable. The evidence from the methods that allow for variation in the bias estimates across the expenditure distribution suggests that CPI during the 1987-1996 period was more overstated for poorer than for richer households. Expenditure-weighted bias estimates range between 2 and 3 percent, with the exception of the sample of tenants where one cannot reject zero bias.

For the second period in study, from 1995/96 to 2002/03, the population sample weighted bias estimate remained above $23 / 4$ percent for all samples but for the tenant sample for which no statistically significant bias was found. For the expenditure weighted bias, which maps to the CPI aggregate basket, estimates range from $2 \frac{3}{4}$ to $4 \frac{1}{2}$ percent again with the exception of the sample of tenants for which no statistically significant bias was found.

In summary, the different estimates are broadly comparable. In our preferred specifications, the bias for the average household is $4 \frac{1}{2}-6$ percent per year in $1987 / 88-1995 / 96$ and $3-$ 5 percent per year in 1995/96-2002/03. The estimates for the aggregate bias, where 
households are weighted by expenditure, are 2-3 percent per year in 1987/88-1995/96 and $2 \frac{1}{2}-4$ percent per year between $1995 / 96-2002 / 03 .{ }^{18}$

\section{Distributional Implications}

The bias estimates shown in Figures 6 and 7 imply a substantial decline in "real" inequality. Figure 8a plots the distribution of CPI-deflated real expenditures, while Figure $8 \mathrm{~b}$ plots the distribution of our estimates of the true real expenditure implied by actual food budget shares in 1995/96 and 2002/03 and the Engel curve in 1987/88. While the distributions in Figure 8a are virtually overlapping, Figure $8 \mathrm{~b}$ indicates a marked improvement, with the distribution moving to the right and becoming more equal.

Table 5 reports the CPI-deflated "headline" and the bias adjusted real expenditure and net income per capita for the average and median households, as well as for the bottom and top quintiles of the expenditure distribution. When expenditure and net income are deflated by the CPI, the largest gains over the sample period are experienced by the top quintile and the gains for the average household are larger than for the median household and the bottom quintile. After correcting for CPI bias, the largest gains are now experienced by the bottom quintile, followed by the median household, the average and the top quintile (but growth is higher for all groups).

Table 6 reports Gini coefficients based on CPI-deflated expenditures and the bias corrected real expenditures (in 1996 reais). The bias correction indicates a substantial decline in the Gini coefficient from $1987 / 88$ to $1995 / 96$, but not from $1995 / 96$ to $2002 / 03$. Much of the improvements in inequality may stem from the inflation stabilization that took place in 1994. Since the poor had more limited access to short-term financial instruments, they were disproportionately burdened by the inflationary tax. Our finding that CPI bias was greater for the poor between 1987/88 and 1995/96 is consistent with the view that the poor were the ones with more to gain from the reduction in inflation. The decline in the relative prices of tradable goods as shown in Figure 5 also has contributed to the narrowing in real expenditure inequality since the poor consume relatively more of that class of goods.

\section{EVIDENCE From DURABLE GOODS OWNERSHIP AND ANTHROPOMETRICS}

Table 7 presents the percentage of households that own different durable goods using data from the POF. It suggests a substantial improvement in the living conditions of Brazilian households. For example, while only 29 percent of households in the POF sample owned a washing machine in 1987/88, 53 percent did by 2002/03. During this same period, the ownership of color TVs increased from 57.4 percent to 93.4 percent. The number of

\footnotetext{
${ }^{18}$ Bias estimates are similar when the sample is constrained to households whose total income is between 1 and 40 times the minimum wage, the target population for which the IPCA index and the relative prices used in our regressions are calculated. Such constraint excludes from the regression sample 2.7 percent, 2.7 percent and 4.7 percent of the weighted households respectively in the $1987 / 88,1995 / 96$, and 2002/03 original samples due to total income lower than 1 minimum wage, and 6.6 percent, 5.3 percent and 5.5 percent, respectively, because household total income is greater than 40 minimum wages.
} 
households that owns either a car or a motorcycle increased from 34.2 percent to 38.1 percent. At first, one may be inclined to dismiss this type of evidence as being driven mainly by declines in the price for these goods and not necessarily by income growth. However, Figure 9 shows that the increase in the ownership of durable goods was skewed toward those goods that are more of a luxury. Figure 9A shows the change in average holdings of a given good between 1988 and 2002 and the sensitivity to income of holdings of that good in the 2002/03 cross-section. That sensitivity is obtained by regressing the household's holdings of that good on the log of total expenditure (instrumented by the log of income) and the same controls as in the previous regression. Figure $9 \mathrm{~B}$ is similar to $9 \mathrm{~A}$ but based on a dummy for ownership of at least one unit of that durable good. Both indicate a disproportionate increase in the demand for goods that are more of a luxury, as expected following the large increase in real income implied by our estimates. The implied increase in real income (controlling for relative price changes) that would explain the change in durable goods holdings and ownership shown in Table 7 and Figure 9 is even higher than the one based on Engel-curves for food consumption (although the estimates are not statistically significantly different from each other).

Table 8 presents the evolution of anthropometric measures of the height-for-age of Brazilian children under 5 years of age. National anthropometric figures are available for 1975, 1989 and 1996. While height has a genetic component, it is also driven by the quality of nutrition, which becomes an increasingly important determinant the further down a household is in the income distribution. As table 8 indicates, there has been a marked decline in the share of children 2 standard deviations or more below the international reference median, which implies a substantial improvement in the nutrition of the poorer households. Table 8 also presents the real minimum wage. As in the case of food demand and durable good ownership, the anthropometric improvements contradict the stagnant real income data. Unfortunately, the recent POFs did not have anthropometric data for children. ${ }^{19}$ It would be interesting to compute the elasticity of these anthropometric measures with respect to measured real income, so as to construct a quantitative estimate of the implied true real income growth (similarly to our analysis for durable goods). This is a very interesting extension once such data becomes available.

\section{Conclusion}

This paper uses household-level data to present evidence that "headline" real household income growth figures in Brazil grossly underestimate the growth in real income. Our estimates indicate that aggregate per capita income during that period grew by $4 \frac{1}{2}$ percent per year. These figures are substantially higher than the $1 \frac{1}{2}$ percent annual "headline" growth obtained by deflating nominal per capita household income by the CPI.

It is possible that similar biases occurred in other Latin American countries, and that such mismeasurement has misguided much of the policy discussion on the effectiveness of marketoriented reforms.

\footnotetext{
${ }^{19}$ The 2002/03 POF did have anthropometric data, but only for people 20 years or older.
} 
Our findings also indicate a substantial improvement in the distribution of income when measured in real terms, particularly between 1987/88 and 1995/96. The real per capita income growth for the typical household was even higher than the aggregate household income growth during that period. This improvement is partly due to the decline in the inflation tax, which likely burdened disproportionately the poor.

This paper focuses on the mismeasurement of households' real income, but similar sources of bias apply for the measurement of production price deflators (e.g., new and better goods). It is unlikely that the GDP deflator was accurately measured if the CPI bias was large, particularly because household consumption, which is deflated by the CPI, is a large component of GDP. ${ }^{20}$

One should not assume that measurement problems associated with the CPI at present are similar to the large bias estimated for 1987-2002. Relative price changes (which amplify substitution bias) were unusually strong in the early 1990s. Quality improvements, a further source of bias, were likely concentrated in the years immediately after tariff reductions. The pooled regression estimates suggest that the bias has declined over time, and much of the estimated bias between the 1995/96 and 2002/03 surveys may stem from the period prior to the 1999 revision of the CPI basket. A new revision will be made in July 2006 (based on the 2002/03 POF), which should further improve the measurement precision. A quantification of the size of the CPI bias in the more recent period with the method used in this paper will only be possible when the results of a new POF become available for comparison with the 2002/03 expenditure patterns.

\footnotetext{
${ }^{20}$ The national accounts system computes GDP from the production side and from the expenditure side, reconciling the two measures. Household consumption accounts for about 55 percent of the expenditure GDP.
} 


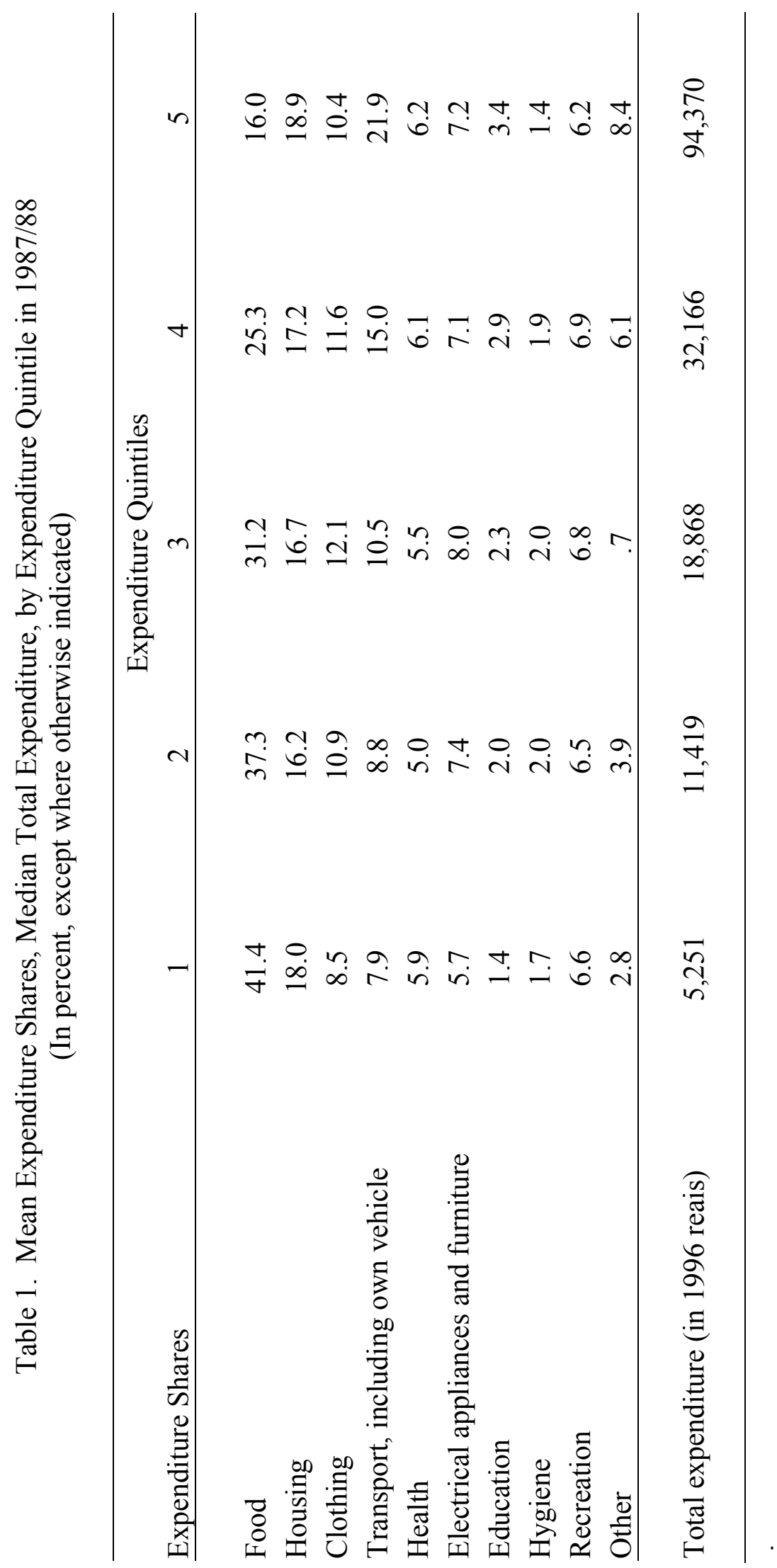




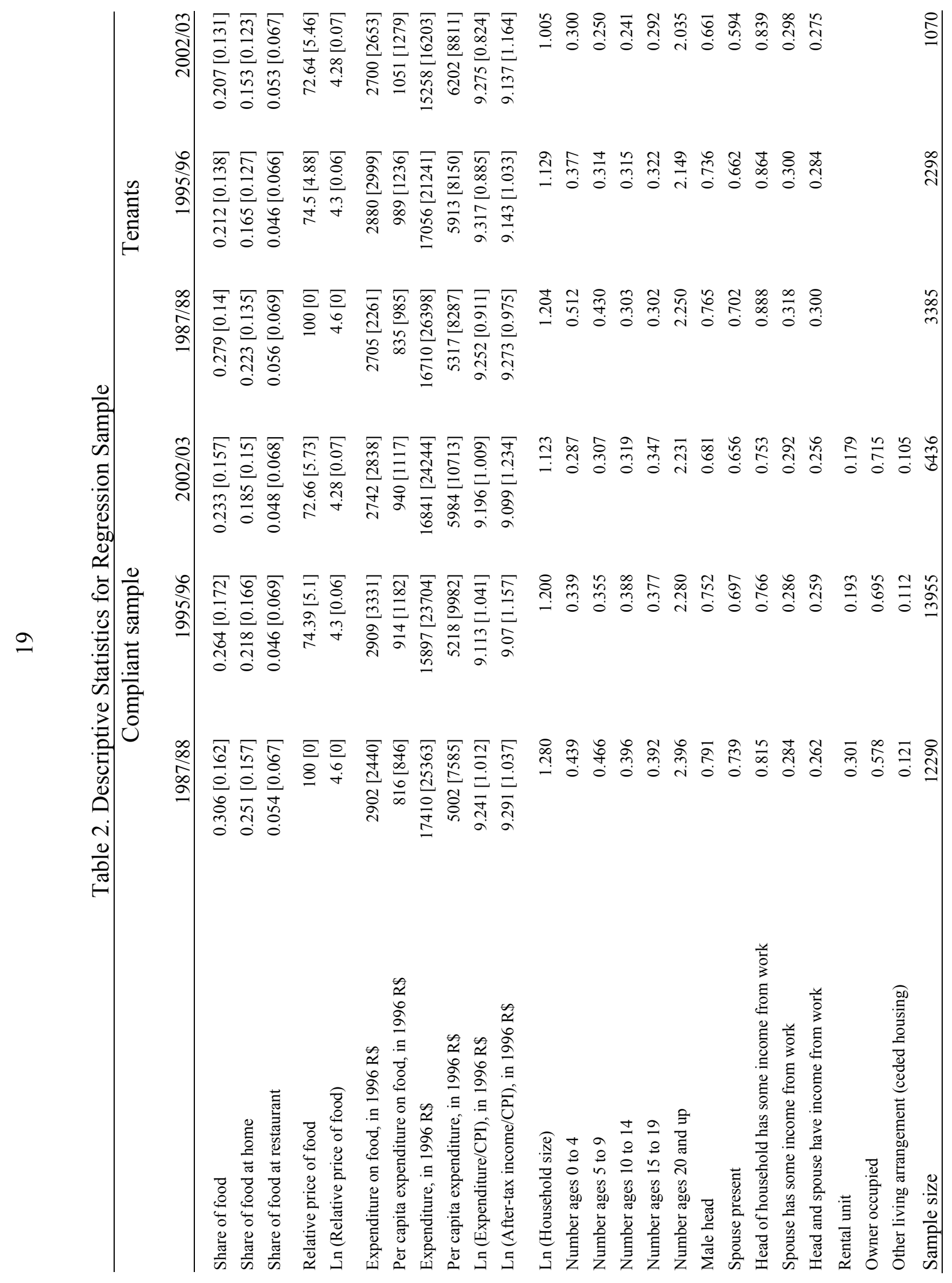


Table 3. Regression Results for Pooled Sample

(Dependent variable $=$ expenditure share of food in 1987, 1996, and 2003)

\begin{tabular}{|c|c|c|c|c|}
\hline & $\begin{array}{c}(1) \\
\text { Tenant -OLS }\end{array}$ & $\begin{array}{c}\text { (2) } \\
\text { Tenant -IV }\end{array}$ & $\begin{array}{c}\text { (3) } \\
\text { Compliant-OLS }\end{array}$ & $\begin{array}{c}(4) \\
\text { Compliant-IV }\end{array}$ \\
\hline Dummy for 1996 & $-0.049[0.016]$ & $-0.047[0.017]$ & $-0.043[0.012]$ & $-0.039[0.013]$ \\
\hline Dummy for 2003 & $-0.05[0.019]$ & $-0.047[0.020]$ & $-0.064[0.013]$ & $-0.057[0.013]$ \\
\hline $\operatorname{Ln}($ Relative price of food) & $0.031[0.050]$ & $0.035[0.054]$ & $0.022[0.038]$ & $0.041[0.038]$ \\
\hline Ln (Expenditure/CPI) & $-0.056[0.005]$ & $-0.076[0.005]$ & $-0.072[0.003]$ & $-0.093[0.004]$ \\
\hline Ln(Household size) & $0.043[0.019]$ & $0.05[0.020]$ & $0.014[0.007]$ & $0.022[0.008]$ \\
\hline Number ages 0 to 4 & $0.004[0.006]$ & $0[0.006]$ & $0.012[0.003]$ & $0.007[0.003]$ \\
\hline Number ages 5 to 9 & $0.006[0.005]$ & $0.004[0.005]$ & $0.012[0.003]$ & $0.009[0.003]$ \\
\hline Number ages 10 to 14 & $0.003[0.006]$ & $0.001[0.007]$ & $0.011[0.003]$ & $0.008[0.003]$ \\
\hline Number ages 15 to 19 & $-0.001[0.006]$ & $-0.002[0.006]$ & $0.009[0.002]$ & $0.008[0.002]$ \\
\hline Number ages 20 and up & $-0.001[0.005]$ & $0.003[0.006]$ & $0.006[0.002]$ & $0.009[0.002]$ \\
\hline Male head & $0.035[0.007]$ & $0.039[0.007]$ & $0.032[0.005]$ & $0.033[0.006]$ \\
\hline Spouse present & $-0.022[0.007]$ & $-0.026[0.007]$ & $-0.014[0.005]$ & $-0.014[0.005]$ \\
\hline Head of household has some income from work & $0.002[0.006]$ & $0.006[0.007]$ & $-0.009[0.003]$ & $-0.004[0.003]$ \\
\hline Spouse has some income from work & $0.011[0.013]$ & $0.014[0.013]$ & $-0.019[0.006]$ & $-0.016[0.006]$ \\
\hline Head and spouse have income from work & $-0.018[0.013]$ & $-0.016[0.012]$ & $0.014[0.007]$ & $0.017[0.007]$ \\
\hline Housing unit ceded by family, employer & & & $0.051[0.006]$ & $0.041[0.005]$ \\
\hline Owner occupied unit & & & $0.024[0.003]$ & $0.023[0.003]$ \\
\hline Constant & $0.62[0.208]$ & $0.775[0.223]$ & $0.853[0.166]$ & $0.93[0.166]$ \\
\hline Observations & 6753 & 6753 & 32681 & 32681 \\
\hline R-squared & 0.224 & 0.21 & 0.295 & 0.283 \\
\hline Cumulative bias 87-96 (\%) & $58.82[13.46]$ & $45.729[13.448]$ & $44.405[9.463]$ & $34.039[9.353]$ \\
\hline Annual equivalent 87-96 (\%) & 9.82 & 6.87 & 6.61 & 4.73 \\
\hline Cumulative bias 96-03 (\%) & $1.081[14.803]$ & $0.398[11.635]$ & $25.298[5.653]$ & $18.07[4.405]$ \\
\hline Annual equivalent 96-03 (\%) & 0.16 & 0.06 & 4.23 & 2.91 \\
\hline Mean dependent variable: & 0.237 & 0.237 & 0.264 & 0.264 \\
\hline
\end{tabular}

Note: Robust standard errors in brackets. Sample excludes observations with no expenditure records in the collective expenditures notebook. Controls also include regional dummies. Total income is used as an instrument to total expenditure in the IV regressions. Cumulative bias reported corresponds to $\left|E_{G, t}\right|$. The implied gross change in the true cost of living is (1$\left.\left|E_{G, t}\right|\right)$ times the gross change in the CPI, and the resulting gross true real income growth is $1 /\left(1-\left|E_{G, t}\right|\right)$ times the gross real income growth obtained by deflating nominal income by the CPI. 
Table 4. Bias Estimates Across Different Methods and Samples

\begin{tabular}{lrrr} 
Population Weighted & \multicolumn{2}{c}{ Expenditure Weighted } \\
$87-96$ & $96-03$ & $87-96$ & $96-03$
\end{tabular}

\section{Parametric Estimates}

Bias Constant Across Households

\begin{tabular}{|c|c|c|}
\hline \multirow[t]{2}{*}{ OLS, Full Sample } & 9.54 & 4.89 \\
\hline & {$\left[\begin{array}{ll}7.2 & 11.7\end{array}\right]$} & {$\left[\begin{array}{ll}3.7 & 6.1\end{array}\right]$} \\
\hline \multirow[t]{2}{*}{ OLS, Compliant } & 6.61 & 4.23 \\
\hline & {$\left[\begin{array}{ll}4.6 & 8.6\end{array}\right]$} & {$\left[\begin{array}{ll}3.2 & 5.3\end{array}\right]$} \\
\hline \multirow[t]{2}{*}{ OLS, Tenant } & 9.82 & 0.16 \\
\hline & {$\left[\begin{array}{ll}4.6 & 14.9\end{array}\right]$} & {$\left[\begin{array}{ll}-2.5 & 3.1\end{array}\right]$} \\
\hline \multirow[t]{2}{*}{ IV, Full Sample } & 6.40 & 3.02 \\
\hline & {$\left[\begin{array}{ll}4.6 & 8.0\end{array}\right]$} & {$\left[\begin{array}{ll}2.1 & 4.0\end{array}\right]$} \\
\hline \multirow[t]{2}{*}{ IV, Compliant } & 4.73 & 2.91 \\
\hline & {$\left[\begin{array}{ll}3.0 & 6.4\end{array}\right]$} & {$\left[\begin{array}{ll}2.1 & 3.7\end{array}\right]$} \\
\hline \multirow[t]{2}{*}{ IV, Tenant } & 6.87 & 0.06 \\
\hline & {$\left[\begin{array}{ll}2.7 & 10.7\end{array}\right]$} & {$\left[\begin{array}{ll}-1.9 & 2.2\end{array}\right.$} \\
\hline
\end{tabular}

Bias Linear Function of Real Expenditure

\begin{tabular}{|c|c|c|c|c|}
\hline \multirow[t]{2}{*}{ OLS, Compliant } & 5.58 & 4.69 & 1.96 & $\begin{array}{r}3.93 \\
265\end{array}$ \\
\hline & {$\left[\begin{array}{ll}4.1 & 7.1\end{array}\right]$} & {$\left[\begin{array}{ll}3.6 & 5.7\end{array}\right]$} & {$\left[\begin{array}{ll}0.4 & 3.8\end{array}\right]$} & {$[2.6$} \\
\hline \multirow[t]{2}{*}{ IV, Compliant } & 4.52 & 3.21 & 2.43 & 3.94 \\
\hline & {$\left[\begin{array}{ll}3.2 & 6.0\end{array}\right]$} & {$\left[\begin{array}{ll}2.4 & 4.0\end{array}\right]$} & {$[0.9$ 4.2] } & {$[2.6$} \\
\hline
\end{tabular}

\section{Semi-Parametric Estimates}

\begin{tabular}{|c|c|c|c|c|}
\hline \multirow[t]{2}{*}{ Tenant } & 3.84 & -0.46 & -0.20 & -0.48 \\
\hline & {$\left[\begin{array}{ll}-1.4 & 8.1]\end{array}\right.$} & {$\left[\begin{array}{ll}-5.2 & 4.2\end{array}\right]$} & {$\left[\begin{array}{ll}-3.7 & 4.7\end{array}\right]$} & {$\left[\begin{array}{ll}-4.2 & 3.3\end{array}\right]$} \\
\hline \multirow[t]{2}{*}{ Full Sample } & 6.14 & 4.84 & 2.83 & 4.32 \\
\hline & {$\left[\begin{array}{ll}4.3 & 8.2\end{array}\right]$} & {$\left[\begin{array}{ll}2.9 & 6.3\end{array}\right]$} & {$\left[\begin{array}{ll}0.9 & 5.3\end{array}\right]$} & {$\left[\begin{array}{ll}2.4 & 6.2\end{array}\right]$} \\
\hline \multirow{2}{*}{ Compliant } & 5.68 & 4.59 & 2.17 & 4.33 \\
\hline & {$\left[\begin{array}{ll}4.3 & 7.9\end{array}\right]$} & {$\left[\begin{array}{ll}3.4 & 6.2\end{array}\right]$} & {$\left[\begin{array}{ll}0.5 & 4.9\end{array}\right]$} & {$\left[\begin{array}{ll}2.8 & 6.5\end{array}\right]$} \\
\hline \multirow[t]{2}{*}{ Winsorized } & 4.94 & 3.58 & 3.04 & 2.83 \\
\hline & {$\left[\begin{array}{ll}3.4 & 6.6\end{array}\right]$} & {$\left[\begin{array}{ll}2.3 & 5.1\end{array}\right]$} & {$\left[\begin{array}{ll}1.7 & 4.7\end{array}\right]$} & {$\left[\begin{array}{ll}1.9 & 3.8\end{array}\right]$} \\
\hline
\end{tabular}

Note: 90 percent confidence interval in square brackets. Full sample stands for all the metropolitan areas for which CPI is available for the three surveys. Compliant sample corresponds to those observations that turned their collective expenditure notebook with at least one expenditure recorded. Tenant sample corresponds to the compliant households that rent their dwellings. Winsorized sample corresponds to the full sample households where the value of food and total expenditures for observations below the $5^{\text {th }}$ and above the $95^{\text {th }}$ percentile are set to the value at that percentile. 
Table 5. Household Per Capita Expenditure and Net Income: Headline and Corrected (in 1996 R\$)

\begin{tabular}{rrrrrr}
\hline & & & & $\begin{array}{r}\text { Annual } \\
\text { percent } \\
\text { change }\end{array}$ \\
\hline
\end{tabular}

Using official CPI as the deflator

$\begin{array}{llrrrr}\text { Household per capita expenditure } & \text { Mean } & 5,003 & 5,219 & 5,985 & 1.2 \\ & \text { Median } & 2,748 & 2,646 & 2,976 & 0.5 \\ & \text { Bottom 20\% } & 790 & 701 & 850 & 0.5 \\ & \text { Top 20\% } & 14,928 & 16,463 & 18,874 & 1.5 \\ \text { Household per capita net income } & \text { Mean } & & & & \\ & \text { Median } & 5,461 & 4,935 & 6,610 & 1.3 \\ & \text { Bottom 20\% } & 2,912 & 2,569 & 2,821 & -0.2 \\ & \text { Top 20\% } & 1,145 & 1,151 & 1,152 & 0.0 \\ & & 15,379 & 13,560 & 20,325 & 1.8\end{array}$

\section{Correcting for estimated CPI bias}

\begin{tabular}{llrrrr} 
Household per capita expenditure & Mean & 4,067 & 5,219 & 7,914 & 4.4 \\
& Median & 1,723 & 2,646 & 3,942 & 5.5 \\
& Bottom 20\% & 335 & 701 & 1,143 & 8.3 \\
& Top 20\% & 14,604 & 16,463 & 24,940 & 3.6 \\
Household per capita net income & Mean & 4,125 & 4,935 & 8,359 & 4.7 \\
& Median & 1,773 & 2,569 & 3,711 & 4.9 \\
& Bottom 20\% & 462 & 1,151 & 1,548 & 8.2 \\
& Top 20\% & 14,500 & 13,560 & 26,219 & 3.9 \\
& & & & \\
\hline
\end{tabular}

Note: Based on estimates of the semi-parametric specification in the "compliant" sample that returned their collective expenditure notebook with at least one expenditure recorded. The bottom and top 20 percent refer to quintiles of expenditure per survey year in this compliant sample. 
Table 6. Expenditure Inequality Corrected for CPI Bias: Expenditure Gini Coefficients

Panel I: Gini coefficients based on CPI deflated expenditures

$1987 / 88$

$1995 / 96$

$2002 / 03$

Panel II: Gini coefficients based on expenditures correcting for the CPI bias

$1987 / 88$

$1995 / 96$

$2002 / 03$
0.533

0.542

0.414

0.398

Note: Based on semi-parametric bias estimates from the "compliant" sample that returned their collective expenditure notebook with at least one expenditure recorded.. 
Table 7. Ownership of Durable Goods and Sensitivity to Income

\begin{tabular}{|c|c|c|c|c|c|c|c|c|}
\hline & \multicolumn{3}{|c|}{$\begin{array}{l}\text { Owns at least one } \\
\text { (percent) }\end{array}$} & \multicolumn{3}{|c|}{$\begin{array}{l}\text { Average number of } \\
\text { units/household }\end{array}$} & \multicolumn{2}{|c|}{$\begin{array}{l}\text { Regression coefficient } \\
\text { income sensitivity }\end{array}$} \\
\hline & $1987 / 88$ & $1995 / 96$ & $2002 / 03$ & $1987 / 88$ & $1995 / 96$ & $2002 / 03$ & At least one & Number units \\
\hline TV & 89.0 & 94.6 & 95.2 & 1.22 & 1.47 & 1.54 & $0.05[0.003]$ & $0.514[0.027]$ \\
\hline Color TV & 57.4 & 83.2 & 93.4 & 0.70 & 1.20 & 1.48 & $0.07[0.004]$ & $0.529[0.027]$ \\
\hline Fan & 52.3 & 64.5 & 67.9 & 0.72 & 0.99 & 1.14 & $0.061[0.008]$ & $0.263[0.027]$ \\
\hline Stove & 98.7 & 99.3 & 99.3 & 1.04 & 1.04 & 1.03 & $0.003[0.001]$ & $0.007[0.003]$ \\
\hline Iron & 90.2 & 92.0 & 91.3 & 1.07 & 1.08 & 1.04 & $0.078[0.005]$ & $0.173[0.028]$ \\
\hline Refrigerator & 87.6 & 91.1 & 94.4 & 0.92 & 0.95 & 0.98 & $0.062[0.004]$ & $0.087[0.005]$ \\
\hline Blender & 83.5 & 84.7 & 85.4 & 0.89 & 0.88 & 0.90 & $0.08[0.006]$ & $0.091[0.02]$ \\
\hline Sound system & 45.8 & 64.1 & 66.8 & 0.49 & 0.72 & 0.76 & $0.135[0.008]$ & $0.228[0.01]$ \\
\hline Bicycle & 30.2 & 40.7 & 39.6 & 0.43 & 0.60 & 0.58 & $0.023[0.008]$ & $0.067[0.014]$ \\
\hline Washing machine & 29.3 & 46.8 & 52.7 & 0.30 & 0.48 & 0.53 & $0.284[0.008]$ & $0.291[0.008]$ \\
\hline VCR & n.a. & 37.9 & 47.9 & n.a. & 0.41 & 0.52 & $0.26[0.008]$ & $0.325[0.009]$ \\
\hline Car or motorcycle & 34.2 & 36.9 & 38.1 & 0.46 & 0.48 & 0.49 & $0.292[0.007]$ & $0.439[0.01]$ \\
\hline Car & 33.0 & 35.6 & 36.1 & 0.42 & 0.45 & 0.45 & $0.294[0.007]$ & $0.422[0.01]$ \\
\hline Cake mixer & 34.8 & 39.1 & 42.1 & 0.35 & 0.40 & 0.43 & $0.215[0.008]$ & $0.217[0.008]$ \\
\hline Hair dryer & 39.6 & 36.1 & 31.0 & 0.48 & 0.42 & 0.35 & $0.224[0.007]$ & $0.289[0.009]$ \\
\hline Water filter & n.a. & n.a. & 36.3 & n.a. & n.a. & 0.37 & $-0.008[0.008]$ & -0.006 [0.009] \\
\hline Microwave oven & n.a. & 16.0 & 30.1 & n.a. & 0.16 & 0.30 & $0.263[0.007]$ & $0.266[0.007]$ \\
\hline Sewing machine & 47.2 & 35.4 & 24.4 & 0.50 & 0.39 & 0.29 & $0.071[0.007]$ & $0.062[0.021]$ \\
\hline Desk radio & 39.5 & 36.0 & 20.8 & 0.46 & 0.44 & 0.25 & $0.049[0.007]$ & $0.099[0.01]$ \\
\hline Portable radio & 38.0 & 28.4 & 20.7 & 0.47 & 0.36 & 0.25 & $0.066[0.007]$ & $0.11[0.01]$ \\
\hline Personal computer & n.a. & 7.0 & 22.2 & n.a. & 0.07 & 0.25 & $0.258[0.006]$ & $0.299[0.007]$ \\
\hline Freezer & 6.9 & 18.8 & 18.8 & 0.07 & 0.19 & 0.19 & $0.131[0.006]$ & $0.137[0.007]$ \\
\hline Vacuum cleaner & 22.4 & 21.7 & 19.0 & 0.23 & 0.22 & 0.19 & $0.22[0.006]$ & $0.226[0.006]$ \\
\hline Air conditioner & 6.4 & 8.6 & 11.0 & 0.10 & 0.13 & 0.16 & $0.103[0.005]$ & $0.196[0.009]$ \\
\hline Toaster & 9.6 & 9.2 & 12.4 & 0.10 & 0.09 & 0.13 & $0.131[0.005]$ & $0.135[0.005]$ \\
\hline Tape recorder & 19.4 & 17.7 & 10.3 & 0.22 & 0.20 & 0.11 & $0.007[0.005]$ & $0.014[0.006]$ \\
\hline Floor waxer & 41.4 & 23.0 & 9.9 & 0.42 & 0.23 & 0.10 & $0.059[0.005]$ & $0.061[0.005]$ \\
\hline Ozonizer filter & n.a. & 6.3 & 9.3 & n.a. & 0.06 & 0.09 & $0.088[0.005]$ & $0.088[0.005]$ \\
\hline Dryer & 4.0 & 9.7 & 6.9 & 0.04 & 0.10 & 0.07 & $0.065[0.004]$ & $0.065[0.004]$ \\
\hline $\mathrm{CD}$ player & n.a. & 7.8 & 7.2 & n.a. & 0.09 & 0.08 & $0.047[0.004]$ & $0.058[0.005]$ \\
\hline Dish antenna & n.a. & 1.7 & 4.5 & n.a. & 0.02 & 0.05 & $0.015[0.003]$ & $0.015[0.003]$ \\
\hline Black and white TV & 57.4 & 25.6 & 5.9 & 0.70 & 0.27 & 0.06 & $-0.015[0.004]$ & $-0.016[0.004]$ \\
\hline DVD player & n.a. & n.a. & 6.6 & n.a. & n.a. & 0.07 & $0.103[0.004]$ & $0.108[0.004]$ \\
\hline Dishwasher & 2.0 & 6.6 & 5.8 & 0.02 & 0.07 & 0.06 & $0.084[0.004]$ & $0.085[0.004]$ \\
\hline Motorcycle & 3.3 & 2.8 & 3.8 & 0.04 & 0.03 & 0.04 & $0.014[0.003]$ & $0.016[0.003]$ \\
\hline LP player & 12.8 & 5.1 & n.a. & 0.13 & 0.05 & n.a. & n.a. & n.a. \\
\hline
\end{tabular}

Notes: Based on the full sample. Regression coefficients are the sensitivity to log of total expenditure for the dummy for owning at least one unit of the durable in question, and for the number of units of that durable. Coefficient was estimated using the 2002/03 POF, with log of income as an instrument for log of total expenditure, controlling for relative prices and for the household characteristics used as controls in the regressions shown in Tables 3 and 4. Standard errors in brackets. The abbreviation "n.a." indicates the relevant data were not available. 
Table 8. Anthropometric Measures for Children 0-60 Months Old

\begin{tabular}{|c|c|c|c|c|}
\hline \multicolumn{5}{|c|}{ Height for Age } \\
\hline Year & Sample & $\begin{array}{c}\text { Percentage Below } 3 \\
\text { Std. Dev. from U.S. } \\
\text { Median }\end{array}$ & $\begin{array}{c}\text { Percentage Below } 2 \\
\text { Std. Dev. from U.S. } \\
\text { Median }\end{array}$ & $\begin{array}{l}\text { Real Minimum Wage } \\
\text { (in } 2006 \mathrm{R} \$ \text { ) }\end{array}$ \\
\hline \multirow[t]{2}{*}{1975} & National & 14.2 & 32.0 & 310.78 \\
\hline & Urban & 10.0 & 25.9 & \\
\hline \multirow[t]{2}{*}{1989} & National & 4.2 & 15.4 & 238.48 \\
\hline & Urban & 3.0 & 12.3 & \\
\hline \multirow[t]{2}{*}{1996} & National & 2.5 & 10.5 & 212.68 \\
\hline & Urban & 1.6 & 7.8 & \\
\hline
\end{tabular}

Note: Anthropometric Data from the World Health Organization Global Database on Child Growth and Malnutrition. Real minimum wage data from IPEADATA. 
Figure 1. Brazil: GDP Per Capita and Average Growth In Decade (Constant 2004 reais)

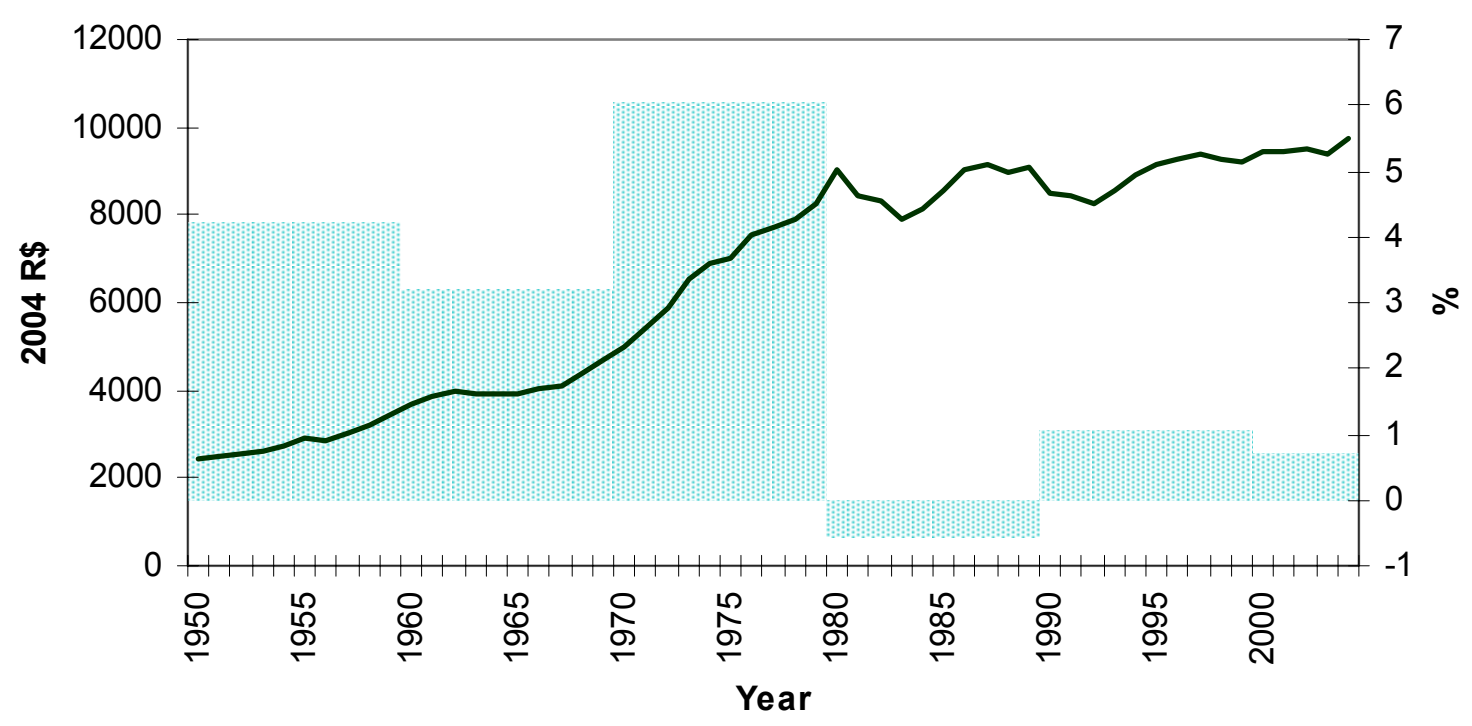

Source: Instituto de Pesquisa Econômica Aplicada (IPEA).

Note: Solid line indicates level while columns indicate average growth rate in decade.

Figure 2. Food Budget Share by Expenditure Deciles

圆 1987/88 $\square$ 1995/96 $\square 2002 / 03$

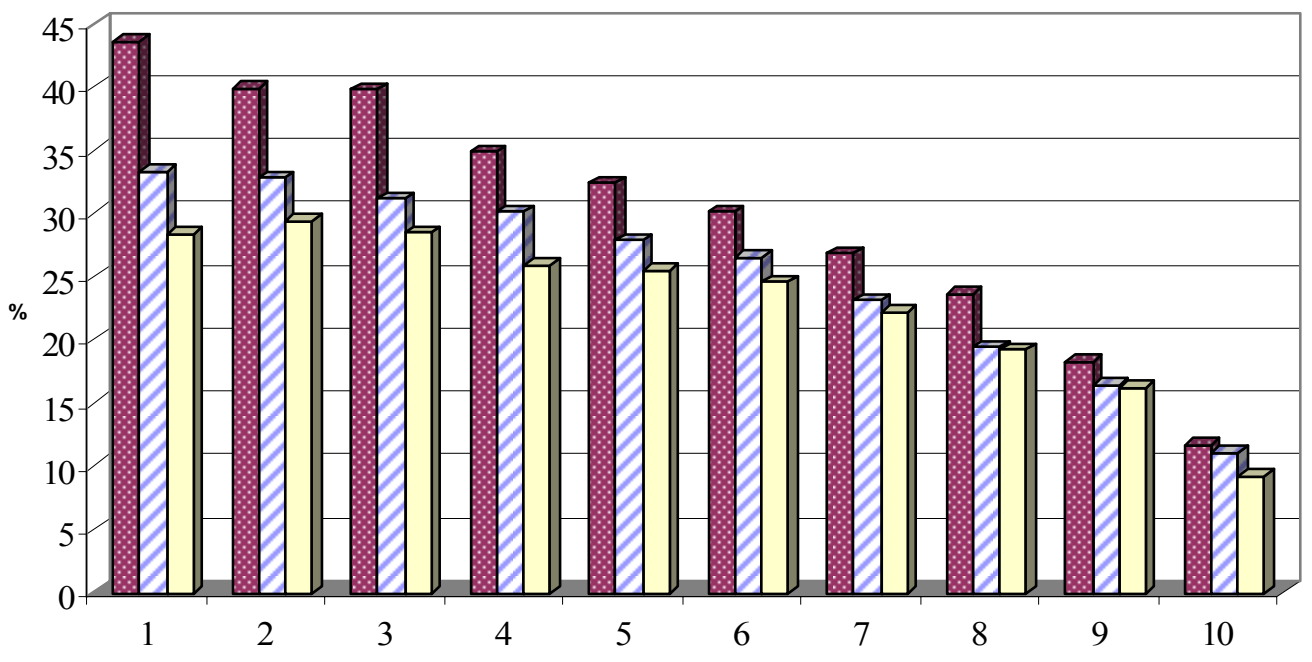

Sources: IBGE; POF; and authors' calculations. 
Figure 3A. Food Budget Share by Metropolitan Area

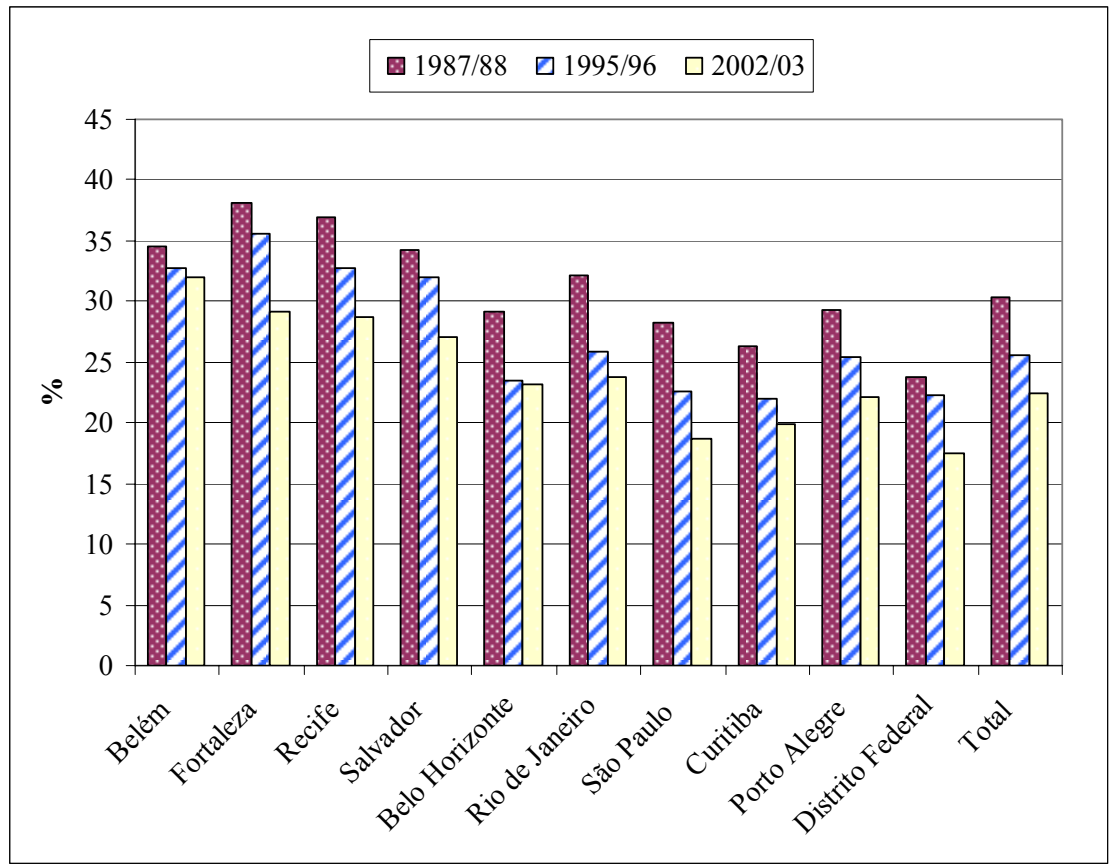

Figure 3B. Food Expenditure Per Capita, by Metropolitan Area (in 1996 reais)

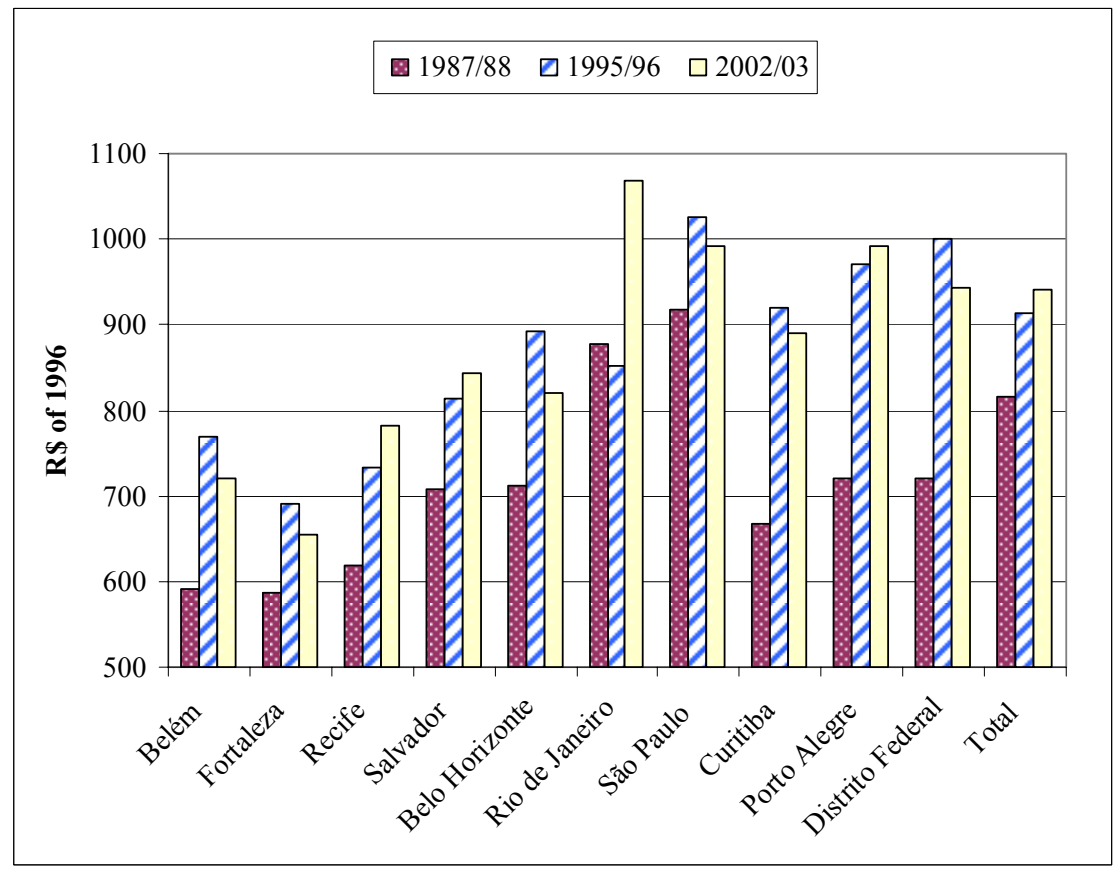

Sources: IBGE; POF; and authors' calculations. 
Figure 4. Changes in Relative Prices

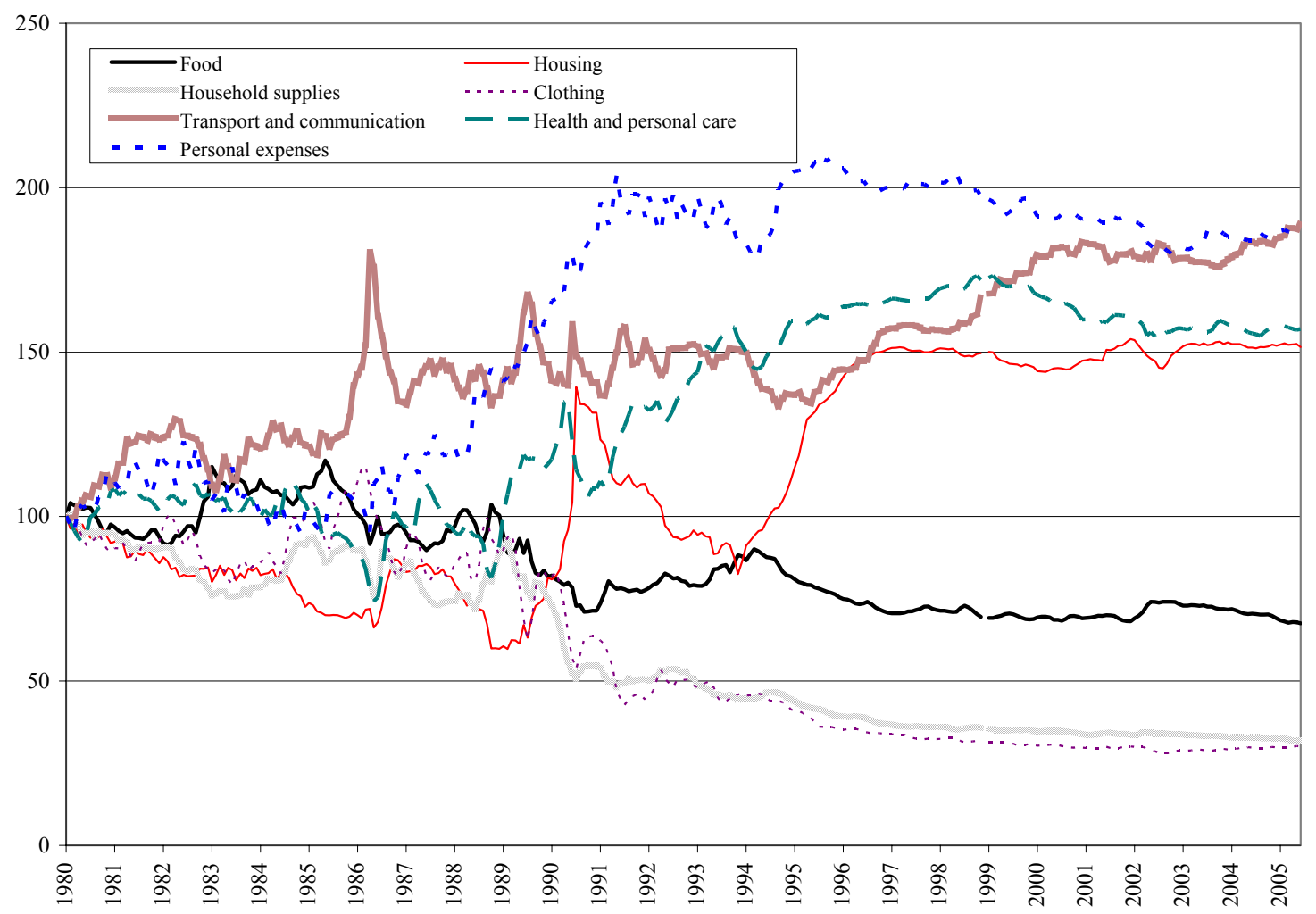

Sources: IBGE; and authors' calculations.

Note: Relative price defined as the ratio of the price level for the group to the level of the overall index. 
Figure 5. Non-Parametric Estimates of Relationship Between Food Shares and Household Expenditure

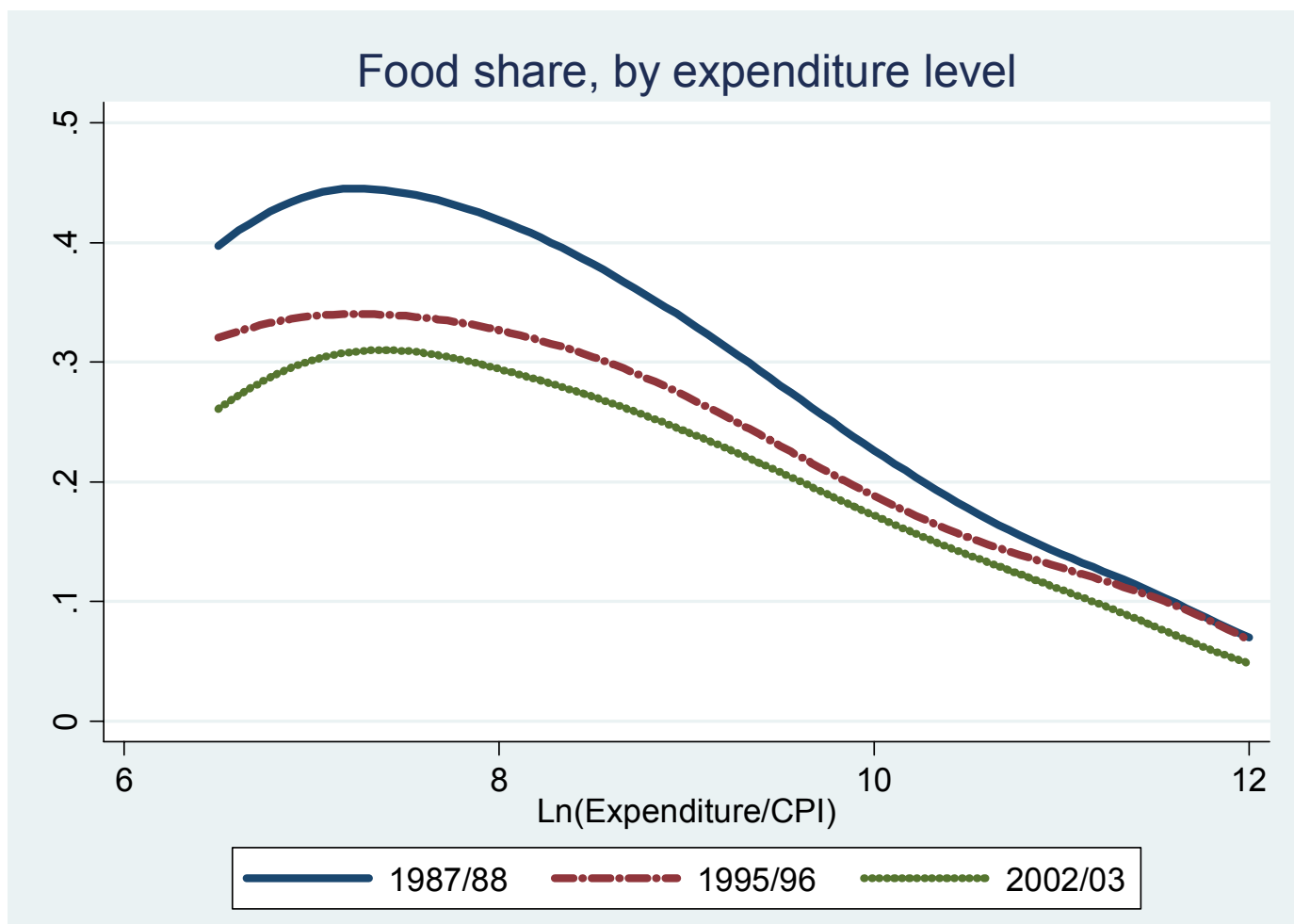

Notes: Estimates based on the full sample. Curves obtained from locally weighted linear regressions using quartic kernel weights. 
Figure 6. Estimated Bias in 1987/88-1995/96 as a Function of CPI-Measured Real Expenditure in 1995/96

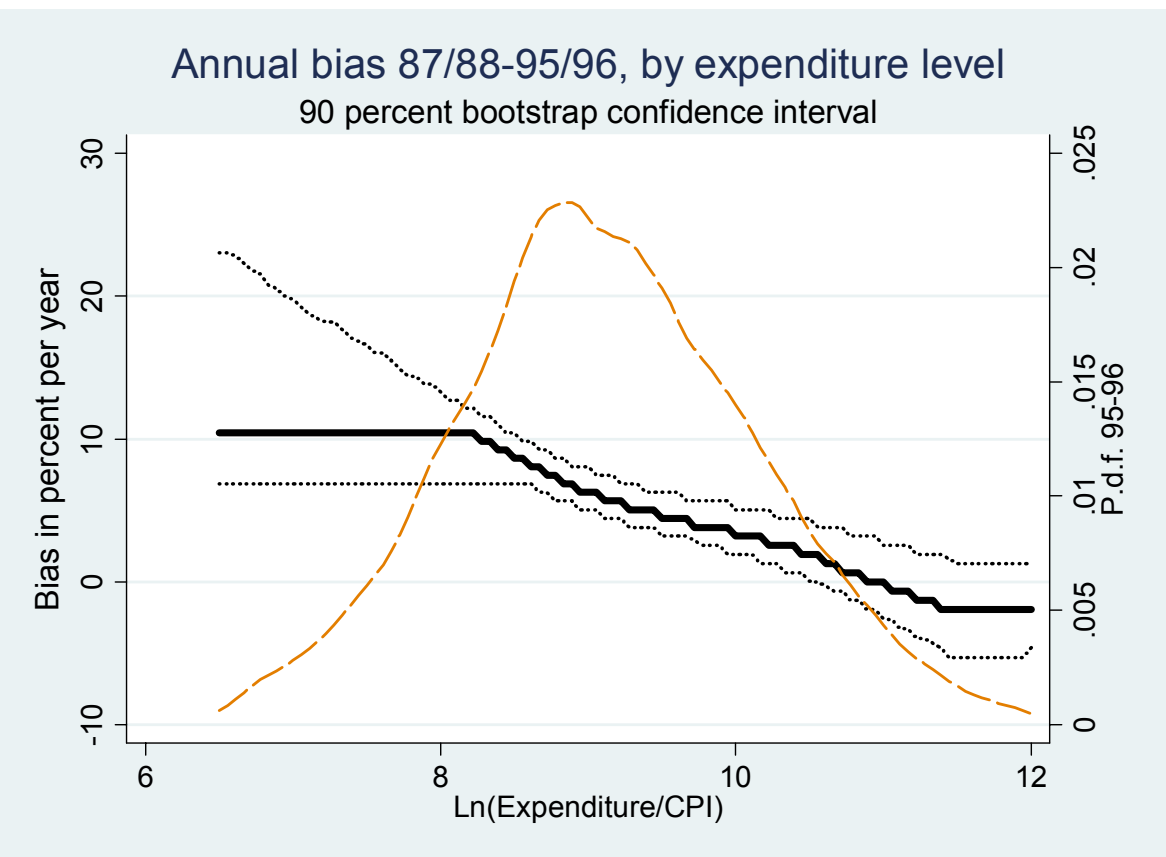

Figure 7. Estimated Bias in 1995/96-2002/03 as a Function of CPI-Measured Real Expenditure in 2002/03

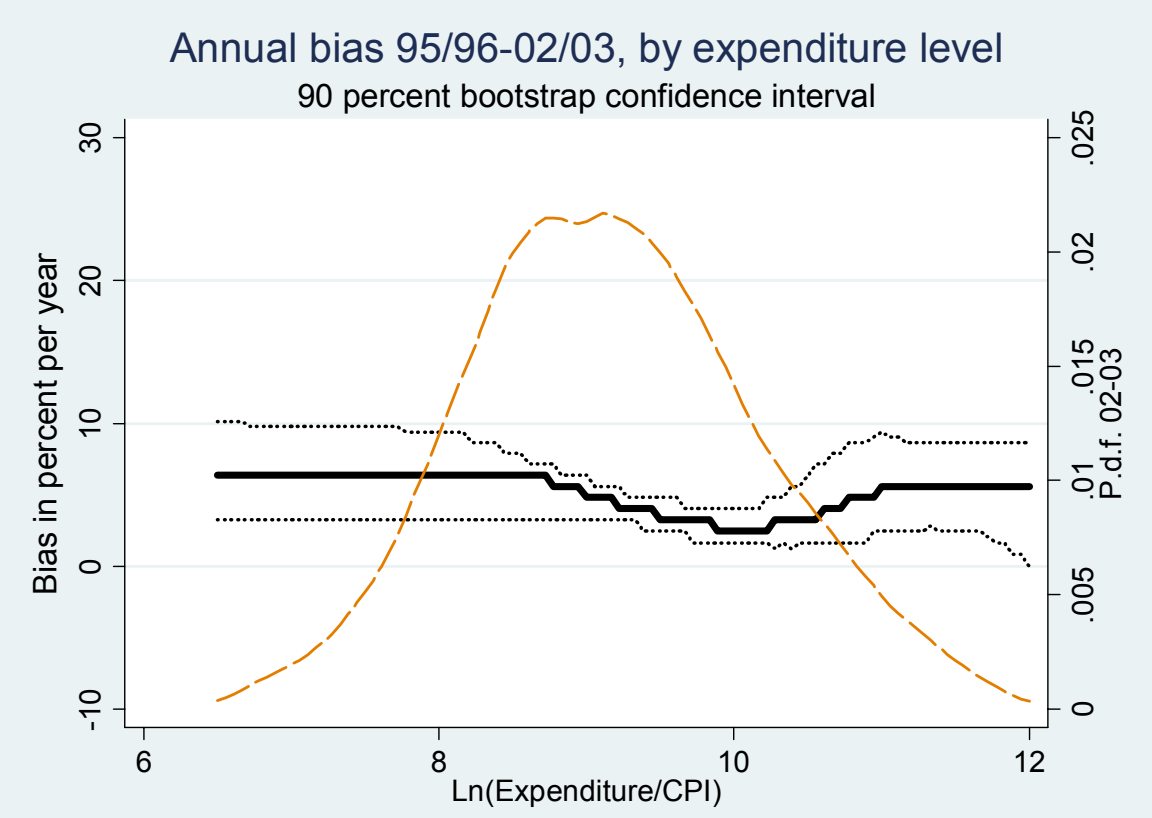

Notes: Bias estimates based on the shift of semi-parametrically estimated Engel curves for the full sample (using the same household characteristics and relative price controls as the regression in Table 3). 
Figure 8A. Distribution of Expenditure Deflated by the CPI: 87/88, 95/96 and 02/03

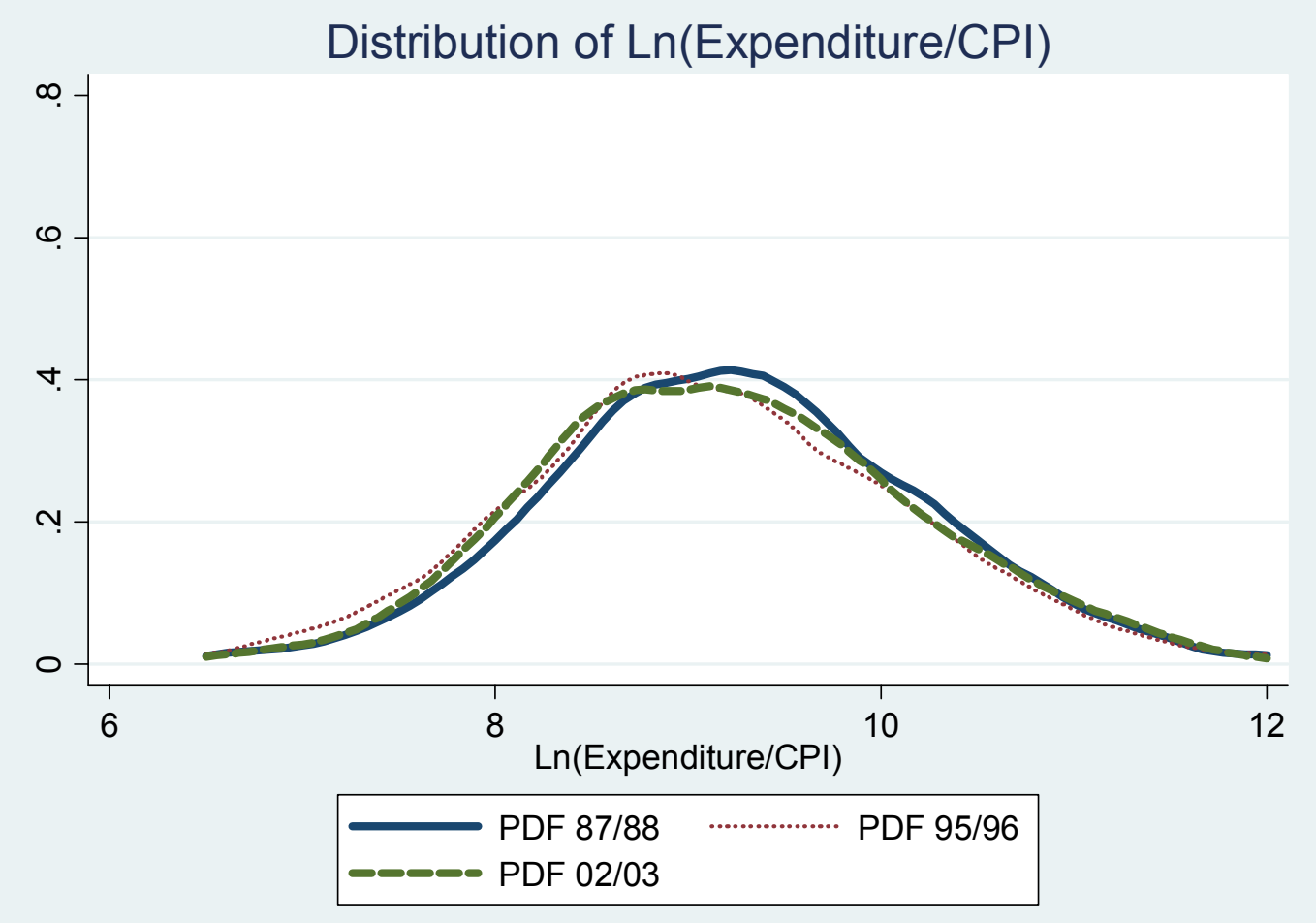

Figure 8B. Distribution of Expenditure Deflated by the Estimated True Cost of Living Index: $87 / 88,95 / 96$ and $02 / 03$

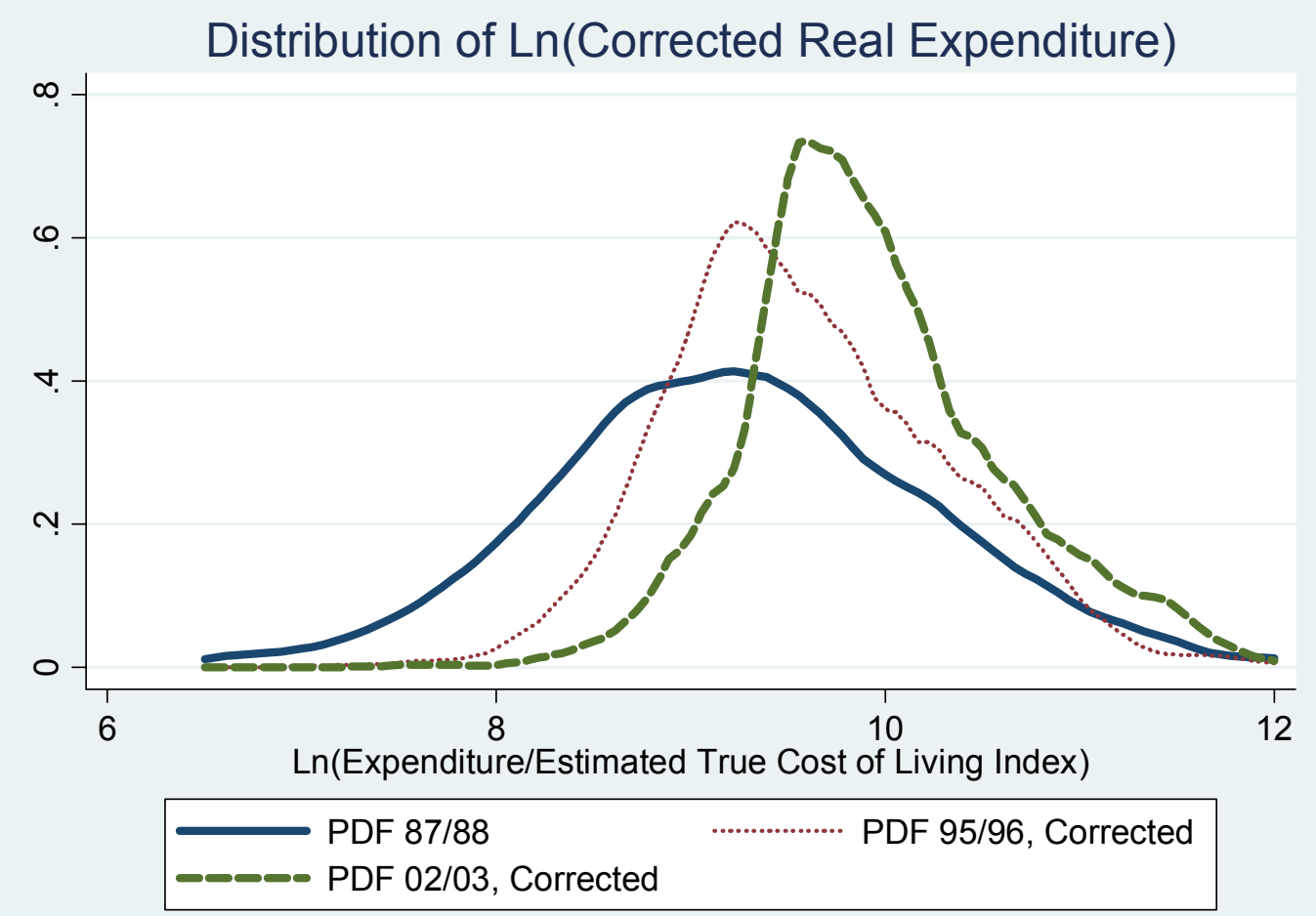

Notes: Bias corrected expenditures based on semi-parametric estimates for the "compliant" sample. 
Figure 9. Changes in Durable Goods Holdings and Sensitivity to Income

\section{Panel A. Average Holdings}

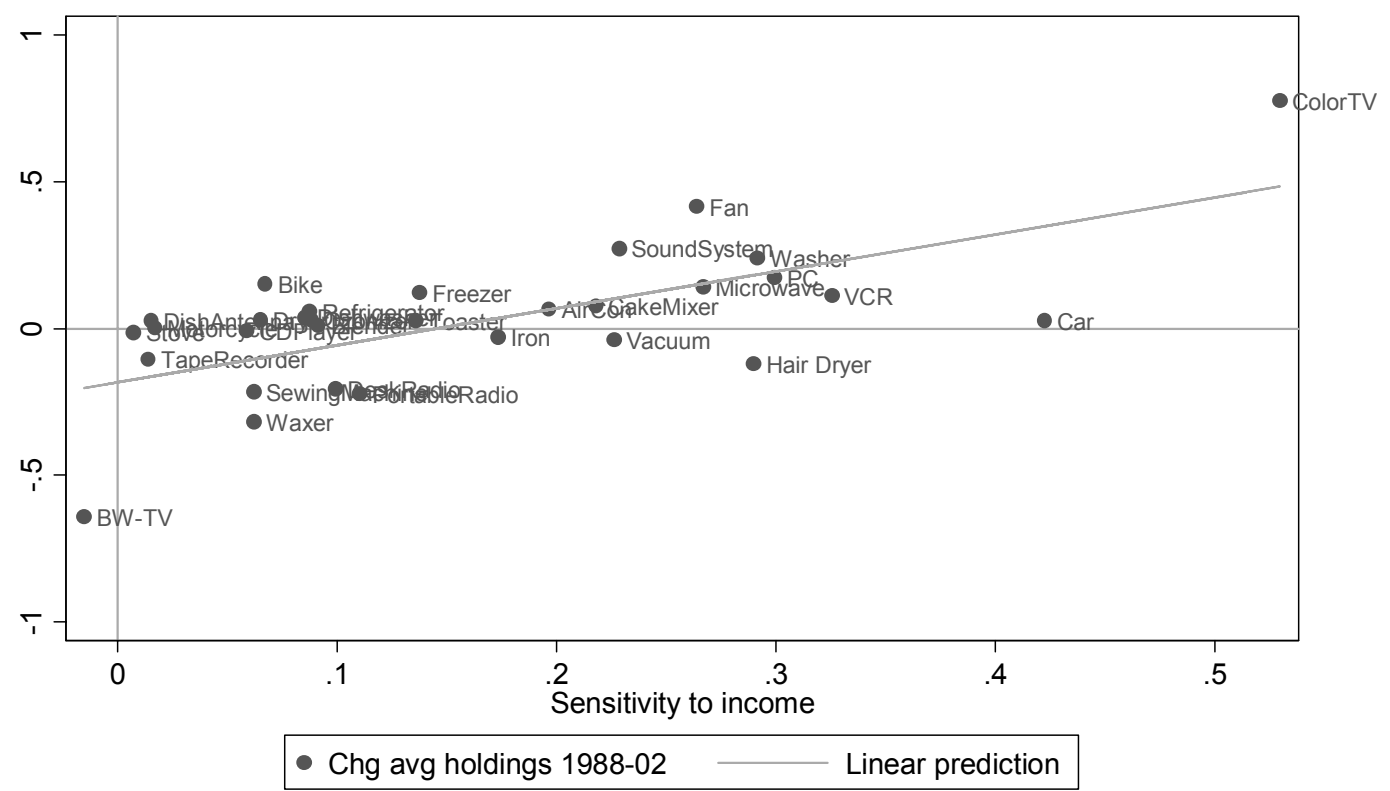

Panel B. Average Dummy for Ownership

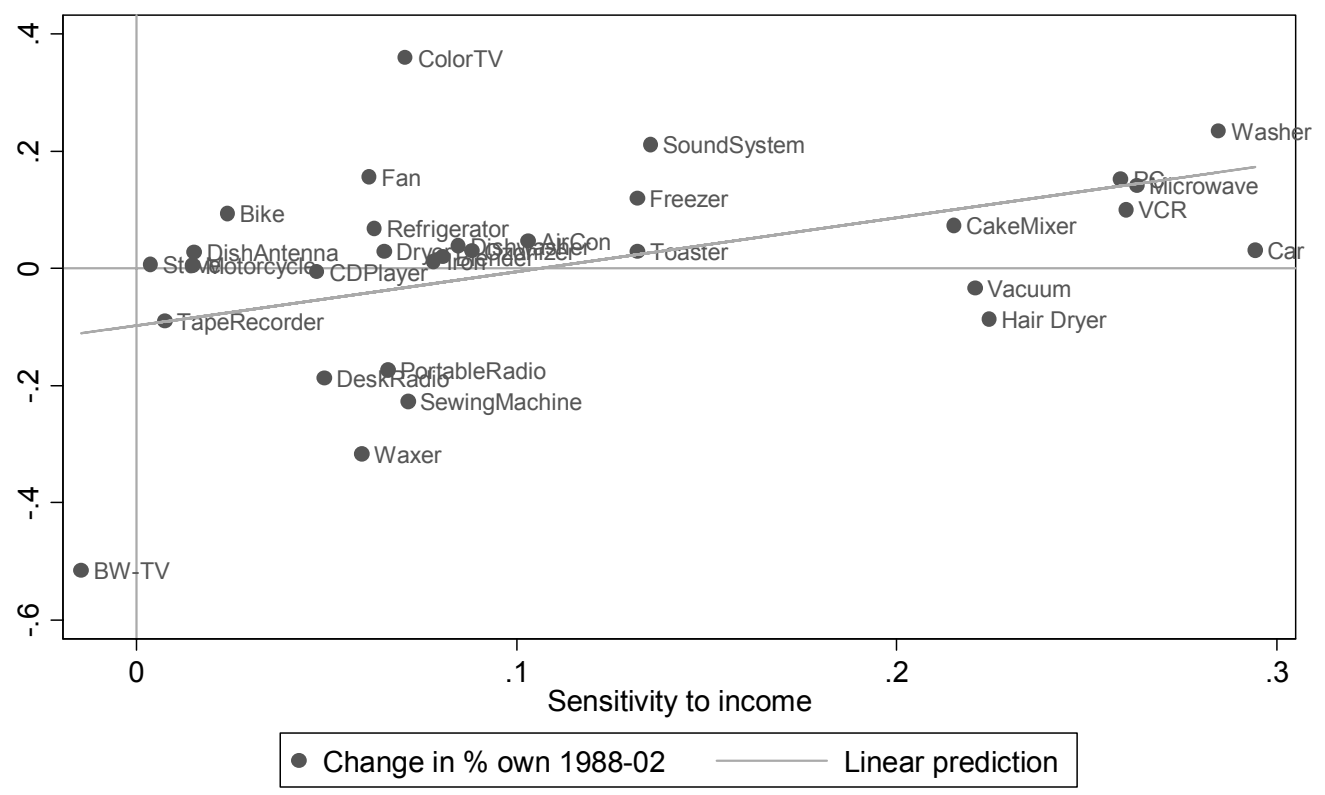

Note: Estimates based on the full sample. Sensitivity to income defined as the coefficient obtained when average ownership or ownership dummy is regressed on log of total expenditure (instrumented by the log of income). The regression also includes controls for relative prices and for the household characteristics described in Tables 2 and 3. 


\section{REFERENCES}

Asano, Seki, and Eduardo P. S. Fiuza, 2001, "Estimation of the Brazilian Consumer Demand System” IPEA Textos para Discussão No. 793 (Rio de Janeiro: Instituto de Pesquisa Econômica Aplicada).

Beatty, Timothy, and Erling R. Larsen, 2005, "Using Engel Curves to Estimate Bias in the Canadian CPI as a Cost of Living Index," Canadian Journal of Economics, Vol. 38, No. 2, pp. 482-99.

Bils, Mark, and Peter Klenow, 2001, "Quantifying Quality Growth," American Economic Review, Vol. 91, No. 4, pp. 1006-30.

Boskin, Michael, Ellen Dulberger, Robert Gordon, Zvi Griliches, and Dale Jorgenson, 1996, "Toward a More Accurate Measure of the Cost of Living," Final Report to the U.S. Senate Finance Committee (December).

Costa, Dora, 2001, "Estimating Real Income in the United States from 1888 to 1994:

Correcting CPI Bias Using Engel Curves," Journal of Political Economy, Vol. 109, No. 6, pp. 1288-1310.

De Carvalho Filho, Irineu, 2004, "Old-Age Benefits and Retirement Decisions of Rural Elderly in Brazil," unpublished (Washington: International Monetary Fund).

Deaton, Angus, and Valerie Kozel, 2005, "Data and Dogma: The Great Indian Poverty Debate," The World Bank Research Observer Vol. 20, pp.177-99.

Deaton, Angus, and John Muellbauer, 1980, “An Almost Ideal Demand System," American Economic Review, Vol. 70, No. 3, pp. 312-26.

Easterly. W., Norman Loayza, and Peter Montiel, 1997, "Has Latin America’s Post-Reform Growth Been Disappointing?" Journal of International Economics, Vol. 43, pp. 287-311.

Ferreira, Pedro, and José Rossi, 2003, "New Evidence from Brazil on Trade Liberalization and Productivity Growth," International Economic Review, Vol. 44, pp. 1383-1405.

Goñi, Edwin, Humberto López and Luis Servén, 2006, “Getting Real About Inequality: Evidence from Brazil, Colombia, Mexico, and Peru," World Bank Policy Research Working Paper No. 3815, January (Washington: The World Bank Group).

Hamilton, Bruce, 2001, “Using Engel's Law to Estimate CPI Bias," American Economic Review, Vol. 91, No. 3, pp. 619-30.

Hausman, Jerry, 2003, "Sources of Bias and Solutions to Bias in the Consumer Price Index," Journal of Economic Perspectives, Vol. 17, No. 1, pp. 23-44. 
Houthakker, Hendrik, 1987, "Engel's Law," in John Eatwell, Murray Milgate, and Peter Newman, eds., The new Palgrave: A dictionary of economics, Vol. 2 (London: Macmillan), pp. 143-44.

Krugman, Paul, 1995, "Dutch Tulips and Emerging Markets: Another Bubble Bursts," Foreign Affairs, Vol. 74, No. 4, pp. 28-44.

Kume, Honorio, Guida Piani and Carlos de Souza, 2000, “A Política Brasileira de Importação no Período 1987-98: Descrição e Avaliação," unpublished (Rio de Janeiro: Instituto de Pesquisa Econômica Aplicada).

Muendler, Marc-Andreas, 2001, "Trade, Technology, and Productivity: A Study of Brazilian Manufacturers, 1986-1998," unpublished (Berkeley: University of California).

Nakamura, Leonard, 1997, "Is the U.S. Economy Really Growing Too Slowly? Maybe We're Measuring Growth Wrong," Federal Reserve Bank of Philadelphia Business Review (March-April), pp. 3-14.

National Research Council (2002). At What Price? Conceptualizing and Measuring Cost-ofLiving and Price Indices, Charles L. Schultze and Christopher D. Mackie, eds.

Neri, Marcelo (1995): "Sobre a Mensuração dos Salários Reais em Alta Inflação", Pesquisa e Planejamento Econômico, 25, no. 3, pp.497-525.

Sachs, Jeffrey D. and Andrew Warner, 1995, "Economic Reform and the Process of Global Integration," Brookings Papers on Economic Activity, 1995, (1), pp. 1-95.

Thomas, Duncan, 1986, “The Food Share as a Welfare Measure,” Ph.D. Dissertation, Princeton University, mimeo.

Yatchew, A., 1997, "An Elementary Estimator of the Partial Linear Model," Economics Letters, Elsevier, vol. 57 (2), pages 135-43 (December). 